Portland State University

PDXScholar

\title{
Soviet Evangelical Students in Adult ESL Classes: A Case Study
}

Patricia Ann Wiggins

Portland State University

Follow this and additional works at: https://pdxscholar.library.pdx.edu/open_access_etds

Part of the Bilingual, Multilingual, and Multicultural Education Commons Let us know how access to this document benefits you.

\section{Recommended Citation}

Wiggins, Patricia Ann, "Soviet Evangelical Students in Adult ESL Classes: A Case Study" (1994). Dissertations and Theses. Paper 4889.

https://doi.org/10.15760/etd.6765

This Thesis is brought to you for free and open access. It has been accepted for inclusion in Dissertations and Theses by an authorized administrator of PDXScholar. Please contact us if we can make this document more accessible: pdxscholar@pdx.edu. 


\section{THESIS APPROVAL}

The abstract and thesis of Patricia Ann Wiggins for the Master of Arts in Teaching

English to Speakers of Other Languages were presented June 22, 1994, and accepted by the thesis committee and the department.

COMMITTEE APPROVALS:

Marjorie Terdal, Chair

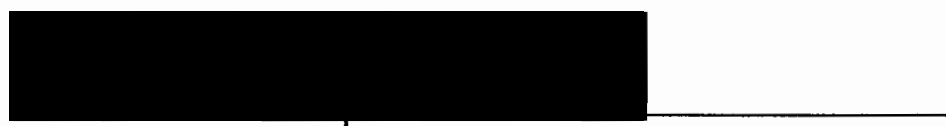

Kimberley Brown
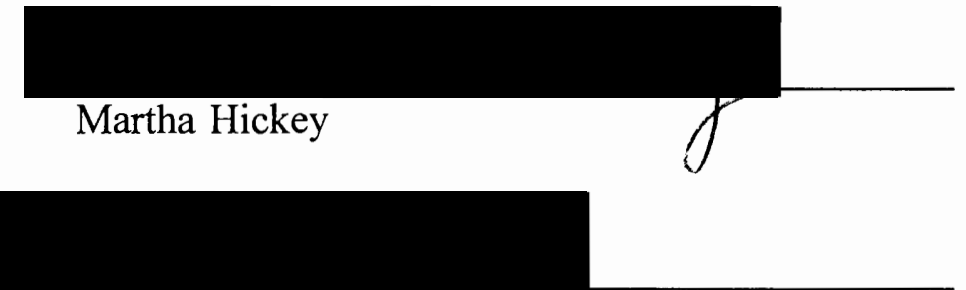

Coyde Hales

Representative of the Office of Graduate Studies

DEPARTMENT APPROVED:

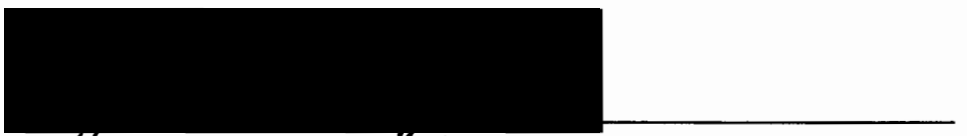

James Nattinger, Chair

Department of Applied Linguistics

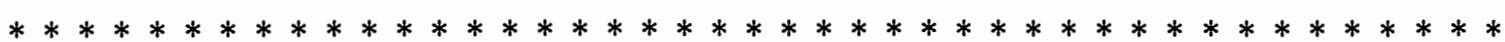

ACCEPTED FOR PORTLAND STATE UNIVERSITY BY THE LIBRARY

by

on

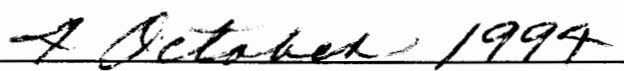




\begin{abstract}
An abstract of the thesis of Patricia Ann Wiggins for the Master of Arts in Teaching English to Speakers of Other Languages presented June 22, 1994.
\end{abstract}

Title: Soviet Evangelical Students in Adult ESL Classes: A Case Study

Soviet Evangelicals (a term inclusive of Pentecostals and other Christians of evangelical persuasion from former Soviet countries) are members of one of the most recent refugee-status groups to come to the United States. Being refugees, they are guaranteed, by the U.S. government, a degree of English language instruction. As a result, since 1989, adult ESL classes in the Pacific Northwest have had a large influx of Soviet Evangelical students.

Because of the scant research as yet conducted on this student population, most ESL educators have had to rely on intuition and observations to interpret Soviet Evangelicals' needs, desires and behavior in the classroom. The purpose of this study was to discover and describe the cultural and educational values of Soviet Evangelicals that affect learning and impact student participation in ESL classes.

Four questions were asked: 1) What are the Soviet Evangelicals' modes of learning? 2) What have been the Soviet Evangelicals' classroom experiences in teacher/student interaction patterns? 3) How do the Soviet Evangelicals view the teacher? 4) What are the cultural values of the Soviet Evangelicals that relate to teaching methods and classroom practice? 
Through a qualitative case study approach, two adult ESL classes were observed for a ten week period, using participant observation methodology. Ethnographic interviews were conducted with five students from one class and four students from a second class. And a survey, designed to elicit preferred modes of learning, was conducted with the students in both classes.

With the data gathered from the research, a cultural framework was developed and implications for teaching were drawn; both of which can be used by ESL educators to make cross-cultural analyses of teaching methods and classroom activities. 


\title{
SOVIET EVANGELICAL STUDENTS IN ADULT ESL CLASSES:
}

\section{A CASE STUDY}

\author{
by \\ PATRICIA ANN WIGGINS
}

A thesis submitted in partial fulfillment of the

requirements for the degree of

MASTER OF ARTS

in

TEACHING ENGLISH TO SPEAKERS OF OTHER LANGUAGES

Portland State University

1994 


\section{DEDICATION}

To My Mother and Father 


\section{ACKNOWLEDGEMENTS}

My sincere thanks and appreciation are extended to my advisor and committee chair, Dr. Marjorie Terdal. From the beginning of my Master's program through the completion of this thesis, she has been both a guide and model of how to be a caring and competent teacher.

Likewise, I am grateful to the other members of my thesis committee at Portland State University: Drs. Kimberley Brown, Loyde Hales, and Martha Hickey. Their expertise in intercultural communication, understanding the Soviet mentality, and general insights into the overall educational dynamic helped shape, and then maintain, the direction of this study.

The two ESL teachers who willingly took part in this study by allowing their classes to be observed and analyzed deserve a special note of thanks. Their graciousness, interest and verbal encouragements were much appreciated and needed along the way.

The student participants in this study were a blessing to me personally. Their stories of courage and faith, instill faith. They were delightful to meet and interview. It is their hope that the re-telling of their thoughts and experiences will benefit others.

To say that my husband, Rob, and my daughters, Jennifer, Lauren and Bethany were supportive of this venture does not communicate the degree of their commitment and support. My husband was my mentor, colleague and cheer leader. My daughters 
encouraged me not to give up, and willingly endured several years with a "studentmom". They share in this achievement, for it has been a family effort. Thank you. 


\section{LIST OF TABLES}

TABLE

PAGE

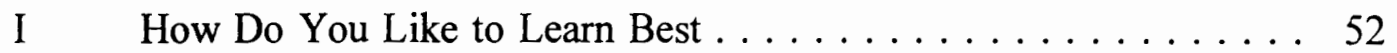

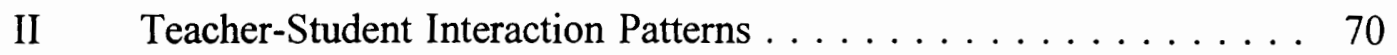

III Cultural Framework/Modes of Learning. . . . . . . . . . . . . . 107

IV Cultural Framework/Teacher-Student Interaction Patterns . . . . . . 109

V Cultural Framework/View of the Teacher. ...........111

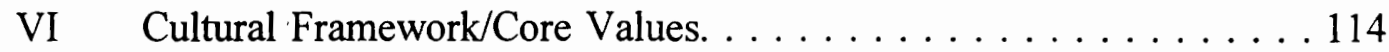

VII Implications for Teaching: Methods \& Interactions . . . . . . . 117

VIIl Implications for Teaching: The Teacher's Role $\ldots \ldots \ldots \ldots \ldots 118$

IX Implications for Teaching: Core Values . . . . . . . . . . . 119 


\section{TABLE OF CONTENTS}

PAGE

DEDICATION $\ldots \ldots \ldots \ldots \ldots \ldots \ldots \ldots \ldots \ldots \ldots \ldots \ldots \ldots \ldots \ldots \ldots \ldots$ iii

ACKNOWLEDGEMENTS $\ldots \ldots \ldots \ldots \ldots \ldots \ldots \ldots$ iv

LIST OF TABLES $\ldots \ldots \ldots \ldots \ldots \ldots \ldots \ldots \ldots$ vi

CHAPTER

I INTRODUCTION $\ldots \ldots \ldots \ldots \ldots \ldots \ldots \ldots \ldots \ldots$

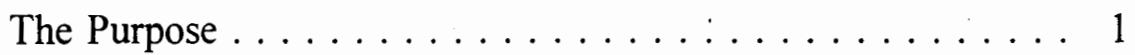

The Problem .................

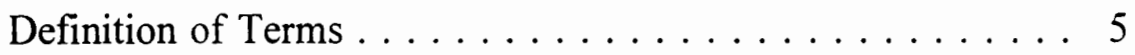

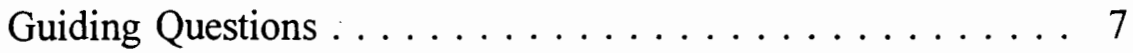

An Approach to the Problem ................ 9

II REVIEW OF THE LITERATURE $\ldots \ldots \ldots \ldots \ldots \ldots \ldots \ldots$

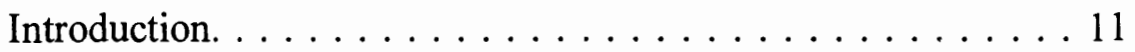

Christianity in the Soviet Union. . . . . . . . . . . 11

Cultural Characteristics of Soviet Evangelicals . . . . . . 15

Education in the Former Soviet Union . . . . . . . . . 18

Culture Conflicts in the ESL Classroom . . . . . . . . 21

Summary ..................... 24

III RESEARCH DESIGN AND DATA COLLECTION PROCEDURES 26

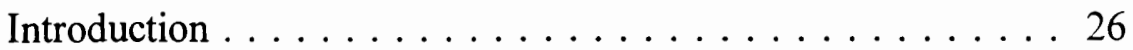

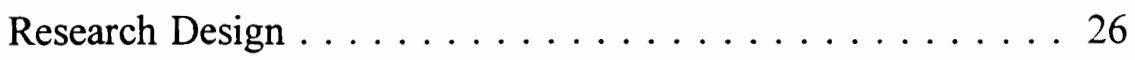

Data Collection Procedures . . . . . . . . . . . 30

Limitations of the Study. . . . . . . . . . . . . 38

Recommendations for Further Study . . . . . . . . $\quad 39$

IV $\quad$ ESL CLASSROOM $\ldots \ldots \ldots \ldots \ldots \ldots \ldots \ldots$

Introduction $\ldots \ldots \ldots \ldots \ldots \ldots \ldots \ldots \ldots$ 
Level $4 \ldots \ldots \ldots \ldots \ldots \ldots \ldots \ldots \ldots$. . . . . . . 41

Level $2 \ldots \ldots \ldots \ldots \ldots \ldots \ldots \ldots \ldots$. . . . . . . . . . . . .

Summary . . . . . . . . . . . . . . 49

V CULTURAL FRAMEWORK: CULTURE IN THE CLASSROOM 50

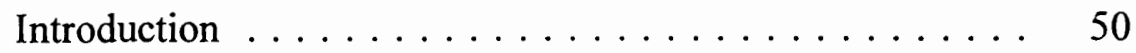

Modes of Learning . . . . . . . . . . . . . . . 51

Interaction Patterns and Activities in Soviet Classes . . . . . 54

Activities and Student Participation in ESL Classes . . . . . 59

Teacher/Student Interaction Patterns in ESL Classes. . . . . 65

Summary . . . . . . . . . . . . . . . . . . . . . 69

VI CULTURAL FRAMEWORK: VIEW OF THE TEACHER . . . 72

Introduction . . . . . . . . . . 72

Status and Prestige ................ 72

The Role of the Teacher . . . . . . . . . . . . . . . . . 77

Experience With Student-Teacher Relationships . . . . . . . 84

Summary . . . . . . . . . . . . . . . . . . 87

VII CULTURAL FRAMEWORK: CORE VALUES $\ldots \ldots \ldots \ldots 88$

Introduction . . . . . . . . . . . . . 88

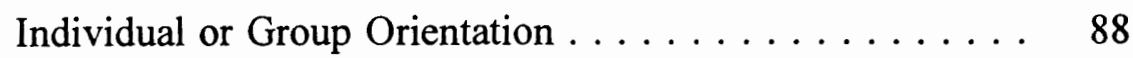

Use of Time . . . . . . . . . . . . . . . . . . . . . . 93

The Value of Education . . . . . . . . . . . . . 96

Summary . . . . . . . . . . . . . . . . 100

VIII SUMMARY AND IMPLICATIONS FOR TEACHING $\ldots \ldots \ldots \ldots 2$

Summary of the Study . . . . . . . . . . . . . 103

Discussion of Findings . . . . . . . . . . . . . . 106

Implications for Teaching $\ldots \ldots \ldots \ldots \ldots \ldots$

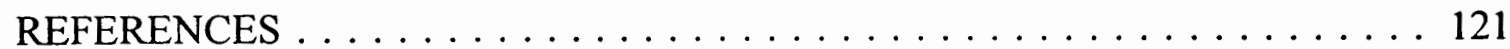

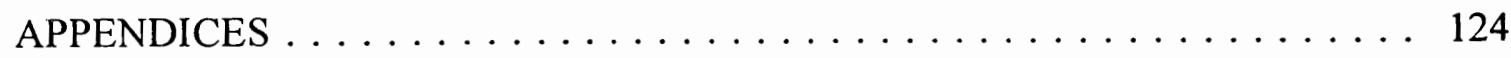

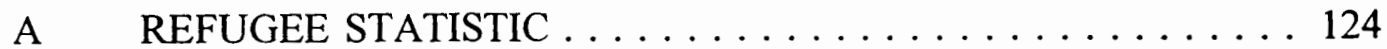

B TEACHING METHODS IN THE SOVIET UNION $\ldots \ldots \ldots \ldots$

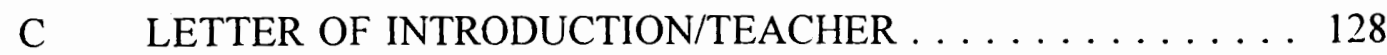


D SAMPLE FIELDNOTES $\ldots \ldots \ldots \ldots \ldots \ldots \ldots \ldots \ldots \ldots$

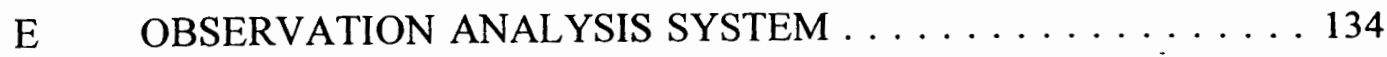

F LANGUAGE LEARNING PREFERENCE SURVEY . . . . . 136

G LETTER OF INTRODUCTION/FOR SE STUDENT . . . . . 138

H INTERVIEW GUIDE $\ldots \ldots \ldots \ldots \ldots \ldots \ldots \ldots \ldots \ldots$

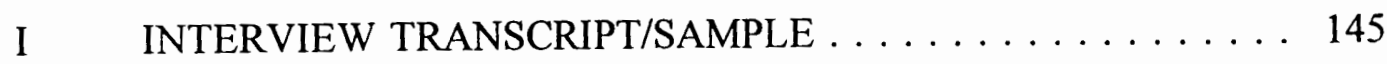




\section{CHAPTER I}

\section{INTRODUCTION}

\section{THE PURPOSE}

The purpose of this study is to explore educational and core values held by the Evangelical Christians from the former Soviet Union (please refer to definition of terms on page 5) who are arriving as refugees in the Pacific Northwest and are students in adult English as Second Language (ESL) classes. The goal of the study is to provide a cultural framework from which ESL teachers can make cross-cultural comparisons that will enable them to be more effective and sensitive educators of this student population. While ESL educators will be the primary benefactors of this study, the need for such a study extends beyond ESL teachers to ESL administrators, teachers of ESL teachers, social workers and refugee field workers.

\section{THE PROBLEM}

A visit to an adult level ESL class reveals the obvious need for language educators to have multi-cultural understanding. While it is common for an ESL teacher to have a class roster with as many as seven or eight nationalities represented, it is also common for a single nationality to numerically dominate an ESL classroom. An observer in one morning ESL class at a local community college will note that the 
former Soviet students heavily out-number the other nationalities; in a second class the population is fairly evenly divided between Southeast Asians and former Soviets (with a single representative from three or four other countries); and in a third class the Southeast Asians out-number the former Soviet students by a large margin.

The current situation in many Pacific Northwest ESL classes seems to be that the Soviet Evangelicals heavily dominate many of the lower and mid-level classes. At the higher levels they may account for about one-third of the class. This influx of a single student population is due to the resettlement of large numbers of Soviet Evangelical Christians from former Soviet Union countries.

Although this type of situation, where one nationality largely outnumbers other nationalities, is not uncommon among ESL classes in the United States, this particular situation presents some unique challenges. Of particular interest to this study is the fact that, while the Soviet Evangelical Christian student population has become a major force in many ESL classrooms, it is a virtually unknown culture group. Whereas much research has been carried out on the cultural values, adjustment factors, and educational preferences of the Vietnamese, for example, very little research has, as yet, been conducted on the former Soviet Evangelical Christian population. Most research and literature dealing with Soviet immigrants focuses on the Soviet Jewish population. While helpful in providing insight into general Soviet culture, the distinctive characteristics of the Soviet Jew are not the same as those of the Soviet Evangelical Christian. Both the Illinois Research Center and the Center for Applied Linguistics in Washington, D.C. have confirmed an absence of research into this most 
recent refugee population. An exception is a recent research study conducted by Amy Roberts for Portland State University dealing with the acculturation of the Soviet Evangelical. Roberts states that not only have social service agencies been caught unprepared for the needs of the Soviet Evangelical, but so, too, is the American educational system unprepared for the special ESL needs and particular learning styles of the Soviet refugees (Locke \& Roberts, 1991).

The fact that almost no research has been conducted on this student population has important implications for ESL teachers. First, adult ESL students arrive in class with their own sets of values, attitudes and beliefs about life in general and classroom practices and etiquette in particular (Furey, 1986). Second, adult ESL students also bring into the class a set of prior experiences in formal education from their national homeland which influence and shape their orientation to learning and participation in the ESL classroom. Furey proposes the need for teachers to seriously consider cultural differences as they decide what teaching methods and classroom practices to employ. The teachers then need to orient their students to the chosen methods and practices. The fact that this particular student population is virtually unknown makes cultural and educational sensitivity difficult if not impossible.

If the influx of this culture group were small or limited in their projected admittance to the United States, perhaps one could argue that it is not necessary to expend the energy needed to investigate the various facets of its character. However, this is not the situation with the arrival of the Soviet Evangelical Christians. Statistics show that the number of former Soviet citizens immigrating to the United 
States jumped from 3,694 in 1988 to a high of 61,298 in 1992 (see Appendix A, Refugee Statistics). Another 55,000 refugees from the former Soviet Union are projected for arrival in 1994 (Refugee Report, Dec. 1993). Refugee processing gives priority to individuals from the former Soviet Union who are Soviet Jews, Evangelical Christians and Ukrainian religious activists (Refugee Report, Dec. 1993). Between 1988 and 1989, when the Soviet Union began issuing exit visas to Jews and to Evangelical Christians, at least 10,000 Soviet Evangelicals reached the United States, with more than 1,000 of that first "wave" settling in Oregon (National Journal, Nov. 4, 1989).

According to John Cleary, a counsellor with International Refugee Center of Oregon, in the past three years, over 5000 former Soviet citizens have been resettled in the Portland area. Of that number, Mr. Cleary estimates that less than $10 \%$ were Jewish. The majority of the remaining $90 \%$ would claim to be Evangelical or Pentecostal.

From these data it is obvious that the influx of this refugee group is neither small in number, nor is it likely to diminish in the immediate future. Along with their size and long term presence, the provision of language education promised to refugees by the United States government in the Refugee Act of 1980 ensures that ESL classes in the Pacific Northwest will have a significant Soviet Evangelical Christian enrollment in the years ahead.

In general terms, Soviet Evangelical Christians have been described by their ESL teachers, educational program administrators, and social service workers as 
somewhat difficult to get along with. They have been called 'manipulative', 'cheaters', and sometimes 'rude and arrogant' toward others in their classes. Several ESL teachers have stated that when their class was heavily populated by the Soviet Evangelical students they were quite overbearing toward the other culture groups. But when they were equal in number or in the minority they were very pleasant and easy to teach. Others have pointed out that it is not uncommon for members of this group to want a separate class for Russians only.

Actions and attitudes such as these may be the result of cultural values and past educational experiences. The ESL classroom is often a culture contact setting where the students' values and expectations on education quite often clash or diverge from that of the teacher and host culture (Furey, 1986). These clashes not only affect the student's learning process, they often lead to personal conflict between the teacher and the student (Fitch, 1986).

Research is needed to gain insight into the culture and past experiences of the Soviet Evangelical Christians which influence their expectations, their behavior and their participation in adult ESL classes.

\section{DEFINITION OF TERMS}

\section{Evangelical}

The movement in modern Christianity that emphasizes conformity to the basic tenets of the Christian faith. It is derived from two Greek words, 'euangelion' and 'euangelizomai', which mean to announce good news (Elwell, 1984). Evangelicalism 
refers to the belief in and speaking to others about the good news of Jesus Christ. Sawatsky (1981) states that evangelical is an inclusive term that refers to all denominations and individuals that conform to the basic tenets of the Christian faith, including sharing that faith with others.

\section{Pentecostal}

Pentecostalism refers to an evangelical reformation movement that began in 1901. Ivan Voronaev, a Russian Baptist, became a Pentecostal in New York and returned as a missionary to Ukraine in 1921 to begin the movement there (Sawatsky, 1981). Voronaev founded over 350 Pentecostal churches before he was arrested in 1929. He died in prison. Pentecostalism emphasizes the use of speaking in tongues (a language that the speaker does not know), often as a sign of being a 'true' Christian, and other 'miracle gifts', such as divine healing (Henderson, 1990). According to Sawatsky, those referred to in American society as Soviet Pentecostals are known as Christians of Evangelical Faith in Ukraine. This research project will not make a distinction between evangelical denominations, but will use the term Evangelical Christian as inclusive of Baptists, Pentecostals and Seventh Day Adventists.

\section{Soviet Evangelical Christian}

The Union of Soviet Socialist Republics (USSR) ceased to exist in 1991. However, for the purpose of this research project, the term Soviet will be used in two aspects. First, as a geographic identification of refugees from countries formerly part of the old Union. Second, it is used as a cultural identification of heirs to the Soviet 
legacy. Through the common educational system they were educated and acculturated under the Soviet regime. Evangelical Christian limits the population to the Christian faith, but expands the study beyond the group commonly referred to as Pentecostals.

\section{$\underline{\text { Refugee }}$}

The Refugee Act of 1980 defines a refugee as a person who is outside of his or her country of nationality who is unable or unwilling to return to that country because of persecution or a well-founded fear of persecution because of race, religion, nationality or membership in a particular social group or political opinion (Refugee Reports, 1980). Although refugees come from divergent cultural background, experiencing multiple kinds of displacement experiences and traumas, they encounter similar kinds of adaptational difficulties. Their common stresses include losses and grief, social isolation, status inconsistency, impact of the traumatic experiences, culture shock, acculturational stresses, accelerated modernization, and minority status (Lin, 1986). While this research project will not attempt to address the acculturation process of the Soviet Evangelical, it is important to note that these stresses enter the ESL classroom along with the student.

\section{GUIDING QUESTIONS}

Because different expectations and interaction patterns between teachers and students can cause conflict, misunderstanding and ineffective teaching and learning, Furey has provided a framework, a cultural checklist, which provides ESL teachers with a basis for investigating and making cross-cultural comparisons (Furey, 1986). 
Four broad questions suggested by Furey are used as the guiding questions investigated by this study. A fifth question relating to ESL teachers' view of Soviet Evangelicals is also asked. Within each of these general areas, more specific questions are addressed.

1. What are the Soviet Evangelicals' modes of learning?

a. How do they like to learn English?

2. What have been the Soviet Evangelicals' classroom experiences in teacher-student interaction patterns?

a. What teaching methods were most often employed--teacher-fronted or learner-centered?

b. What has been their experience in student participation in the classroom?

3. How do the Soviet Evangelicals view the teacher?

a. What are their perceptions of teacher status and prestige?

b. What are their expectations of the teacher role?

c. What has been their experience with student/teacher relationships?

4. What are the cultural values of the Soviet Evangelicals that relate to pedagogy (teaching methods) and classroom practice?

a. Do they have an individualistic or group orientation?

b. What is their attitude toward use of time?

c. What is their view of the purpose of education?

5. How do their ESL teachers view Soviet Evangelicals?

a. What are their perceptions of SE students' values? 
b. What has been their experience with student/teacher relationships?

c. What are their expectations of SE students academically?

\section{AN APPROACH TO THE PROBLEM}

To understand behaviors and attitudes expressed either verbally or non-verbally by students in second language classrooms, it is necessary for teachers and administrators to put themselves in their students' places. They must look out from their students' "cultural lenses". In order to gather the cultural data suggested by the research questions, this study uses a qualitative case study research design. A qualitative case study is appropriate for the problem addressed by this research study because it allows for the use of multiple field techniques (Merriam, 1988).

Ethnographic interviewing is used to gain first hand understanding of the Soviet Evangelicals' culture. While an ethnography is a "complete account of a particular culture, case studies examine a facet or particular aspect of the culture...under investigation" (Nunan, 1992, p.77). In this study, the facet studied is the relationship between the Soviet Evangelicals' cultural background, particularly their educational background, and their participation in American ESL classes. Thus, ethnographic interviewing of Soviet Evangelical students is an integral part of the design.

Using a case study design also allows classroom observations through the medium of participant observation. Understanding the cultural background of a student population is only part of an ESL teacher's need. Of equal importance is 
understanding how that culture is "acted out" in the classroom. Thus, participant observation becomes a second aspect of data collection in this study.

A third element of data collection is the administration of a survey designed to obtain input from the the SE students on how they like to study English.

A qualitative study as opposed to a quantitative study is used in this study because case studies are an appropriate means of research when the desired objective is a focus on "humanistic outcomes or cultural differences" rather than "behavioral outcomes or individual differences" (Merriam, 1991, p.30). While quantitative measures can be used for many purposes, such studies are premature to an understanding of the cultural and educational orientation of the Soviet Evangelical student population. This case study is suggested as a beginning point to gain understanding of an unstudied culture. 


\section{CHAPTER TWO}

\section{REVIEW OF THE LITERATURE}

\section{INTRODUCTION}

Who can forget the picture of Khrushchev pounding his shoe on a podium and shouting at the American people, "We will bury you!"? Or separate themselves from the long years of the cold war, the Iron Curtain, and the competition for world power that has dominated relations between the United States and the Soviet Union? The 'Russians' have long been an enigma, a mysterious and fearsome nation, to the people of the United States. And yet, with the dissolution of the Soviet Union and the open door policy it has taken toward its former religious dissidents, the United States finds itself the 'safe harbor' of many who once were considered part of 'the enemy'---the Soviet Evangelical Christian has become America's newest religious refugee.

\section{CHRISTIANITY IN THE SOVIET UNION}

\section{Religious History}

Russian Orthodoxy has been the state religion of Russia for almost a thousand years. It was one of the few religious denominations legally permitted under communist rule. In explaining the background of the Ukrainian and Russian people, Svitlychna (1985) says that they are traditionally a religious people, tracing their 
Christianity to the Kievan Rus' in 988. In every ethnic Russian there is an Orthodox heritage (Richmond, 1991).

Evangelical Christianity was introduced into Russia in the 19th century through Baptist and Plymouth Brethren missionaries with the Baptist remaining the largest protestant denomination (World Relief, 1989). Pentecostalism appeared in the early 1900's. By 1924 Pentecostal believers had extended themselves to the entire Ukraine. The Pentecostal movement experienced exceptional growth in the two decades following World War II. By the early 1960s there were approximately 250,000 Pentecostal believers in the U.S.S.R., especially in Ukraine and in Siberia (Encyclopedia Britannica, 1973).

Pentecostal believers differ from other Evangelical Christians in placing a stronger emphasis on the Holy Spirit, which Pentecostals say gives them strength and power to live a victorious Christian life. In the main tenets of Christianity, however, all Evangelicals hold to the same beliefs (Sawatsky, 1981). Along with the Baptists and Pentecostals, there are also Seventh Day Adventists and Mennonites of Evangelical faith.

\section{Persecution of Evangelical Christians}

Christianity in the Soviet Union experienced unprecedented persecutions during the 1930s (Sawatsky, 1981; World Relief, 1989). In 1929 state officials, together with voluntary organizations of so-called 'militant godless', launched an aggressive attack on religion, and evangelicals in particular. They used propaganda and 'administrative measures' to accomplish their tasks. In the Stalinist era, persecution involved more 
than destroying the top leadership of the church. Local pastors were arrested, charged with taking part in cult activities or for having foreign friendships, which were regarded as traitorous, and sent to prison. Some of the leaders escaped arrest by going into hiding and there managed to conduct secret meetings.

The Khrushchev anti-religious campaign of 1959 to 1964 was equally rigorous in its persecution of the religious. Many churches were closed and those that remained open had to follow many restrictions. All churches were required to register with the government in order to be considered legal. This registration gave the government access to membership records. The Pentecostal denomination was never recognized by the government because of its refusal to sign an oath of loyalty and its refusal to register with the government. Being unregistered, it remained illegal, and a prime target for government sanctions (Sawatsky, 1981). "They have particularly suffered because they are viewed, in the words of unpublished Soviet legislation as 'anti-Soviet and suspicious'" (World Relief, 1989, p.3).

Becoming an evangelical Christian in the Soviet Union meant living with many hardships. Religious education of children and youth meetings were forbidden by law. While religious education in the home was not forbidden, it was 'discouraged'. The religious, says Sawatsky (1981), lived with the constant fear of arrest for some action that was deemed illegal. Homes that were suspected of being secret meeting places of Christians were routinely, but unexpectedly, inspected for illegal documents and activities. Men and women were imprisoned for handing out Bibles and literature, and for holding Bible classes for children. Parents lived under the threat of having their 
children removed from their homes and placed in state-run boarding schools where they would be taught Communist ideology (World Relief, 1989).

The government used the church's ordinance of baptism as another means of persecution and control. There was often a time span of several months between the time an individual asked to be baptized and the actual baptism (in registered churches). During the waiting period, the individuals' colleagues at work would try to persuade the Christian against joining the church. Authorities, whether in the workforce or government agencies, typically threatened believers in order to get them to renounce their beliefs. Svitlycha (1985) tells of Pentecostals being beaten, imprisoned and sentenced to long prison terms for maintaining their beliefs. In addition to persecuting Pentecostals and other Evangelicals for holding religious meetings, possessing religious literature, bringing up their children in a religious spirit, and refusing to take the military oath, she says they were also persecuted for requesting permission to emigrate.

Religious persecution had no age limits in the Soviet Union. The school system was one of the primary agents for eliminating religion from the minds and hearts of the people. It was "potentially the most powerful weapon the government had in its struggle against religion" (Powell, 1975, p.51). Resourceful teachers, states Powell, would weave attacks on religious beliefs and persons into any kind of lesson. Physics, geography or literature, for example, could serve as jumping-off points for teaching children about the evils or falsity of religion. Children of Evangelical believers were often ridiculed by teachers and fellow classmates. Christian students with high marks 
were denied access to higher education and prestigious jobs (Sawatsky, 1981; World Relief, 1989).

Although the persecution of the religious has lessened considerably in the last few years, the effects of such experiences have a lasting impact on the lives of those who lived through the years of persecution and on the lives of their descendants.

\section{Worship Services}

A typical Soviet Evangelical worship service differs considerably from American Evangelical services. According to Sawatsky (1981) it begins with congregational singing, flavored with a distinctive Slavic melancholy. This solemn and serious attitude toward spiritual matters marks a significant difference from American church services. Usually three or four sermons are given by different individuals, followed by more singing and prayer. Light-heartedness and laughter has no place in Soviet Evangelical services, which usually last two to three hours. Typically, Soviet Evangelicals meet for worship at least twice on Sunday and three times during the week. During the service itself the women and men are separated, with the men sitting on one side of the sanctuary and the women on the other (Sawatsky, 1981; World Relief, 1989).

\section{CULTURAL CHARACTERISTICS OF SOVIET EVANGELICALS}

Some of the uniquenesses of Soviet Evangelicals emerge from their adherence to Biblical teaching and their adherence to faith during the years of the Communist government's repression of religion. But in their basic values and cultural 
characteristics they cannot be separated from their culture at large. While the Soviet Evangelicals span the breadth of the vast former Soviet Union, the majority of the students in ESL classes have a Russian/Ukrainian heritage. Therefore, the insights shared by Richmond (1992), in From Nyet to Da, provide an insightful and enlightening analysis of the Russian personality which can be viewed as applying to most of the SE students coming to the United States. Richmond states:

The Russian character, formed over centuries by unique experiences and traditions, has made Russians different from other Europeans as well as from Americans. The characteristics described here may not apply to all Russians, but Americans can expect to see them in most of the Russians they will meet. (p.xv)

While Richmond's work describes the Russian character as it has developed over a long period of time, it includes the Soviet Evangelical as a part of that Russian culture.

\section{Social Relations/The Role of the Groun}

Unlike Americans, who view individuality and privacy as 'god-given rights', Richmond states that the Soviet people as a whole view group consensus as of primary importance. The affinity of the group has deep roots in Russian culture. 'Sobornost' (communal spirit), which distinguishes Russians from Westerners, can be traced back to the 'mir', an agricultural village commune based on territory and mutual interests. Family members lived side by side, with the surrounding unfenced land being held in common by the mir. The mir made and enforced the communal rules. This communal way of life, says Richmond, has persisted well into the twentieth century. Even as Russia became less agricultural and more urban, the 'mir' mentality followed the peasant into the city. 
According to Richmond, individualism, while esteemed in America, has a pejorative meaning in Russian. Russians think of themse!ves as members of a community, not as individuals. As members of a community they feel an obligation and a right to 'intrude into the private affairs of others" (p. 19). It is common for older Russians to admonish or give advice to younger men and women.

Creating and maintaining a consensus, whether in religion or in politics, is seen as desirable, and dissidents are seen as somewhat strange. While America enjoys a pluralism of beliefs and truths, at times encouraging dissenters from these truths, Russia has a traditional disdain for dissidents. The Russian word for dissidents, "inakomyslyaschi", actually means "persons who think differently" (p. 27).

This sense of belonging to a group is also seen in Russian egalitarianism. While many Americans are raised on the hard work ethic -- work hard and get ahead in everything you do, Richmond states that Russians believe it is morally wrong to get ahead at the expense of others. Equality to the Russian mind does not mean fairness and equality of all people before the law, but it means the "removal of inequities among people and a more equal distribution of benefits" (p.35).

The Russian sense of belonging to a group combined with their notion of egalitarianism, leads the Russian people to a sense of respect for authority, but not an intimidation by authority. They regard themselves as co-equal with others and are not hesitant to speak up in public, or to assert themselves in meetings. Neither are they hesitant about forcefully requesting things that they believe are rightfully theirs. 


\section{Sense of Time/Activity}

Unlike those Americans who view time as money and punctuality as a virtue, Russians' view of time comes from their agricultural heritage. It is like seasons, there is a time for things to happen. Being 'on time' is virtually alien to Russians. Richmond comments that "Russians are notoriously not on time, and they think nothing of arriving long after the appointed hour, which is not considered as being late" (p.122). For Russians, time is not measured in minutes and hours, but in days, weeks and months. While punctuality is an American virtue, patience is a Russian virtue.

In like manner, Americans tend to be oriented toward 'doing' things. They want to accomplish their goal in a minimum amount of time and move on to the next project. They have grown up believing that the concepts of adventure, accomplishment and risk-taking are positive values. The Russians, however, are oriented toward thinking and analyzing. They value "stability, security, social order, and predictability, and to avoid risk. The tried and the tested is preferred over the new and unknown" (Richmond, p. 39).

\section{EDUCATION IN THE FORMER SOVIET UNION}

The purpose of public education, in the former Soviet Union was to train and develop builders of communist society. One of its principal objectives was to "inculcate communist ideology and moral principles, which presupposes a scientific understanding of nature" (Zverev, 1983, p.23). 
From their earliest days in school, attitudes of working for the common good were fostered (Powell, 1975; Zverev, 1983). One should work for public benefits, not merely for personal profit. The underlying theory behind the curriculum was harmonious development of personality and the need for a well trained work force (Powell, 1975; Zverev, 1983).

Zverev believes that there was a growing interest among Soviet educators to teach the younger generation to be creative and self-reliant, directing the students to be doing socially-useful work. In devising teaching methods, he states that the teacher should not rely on dogmatism, classroom academics, authoritarianism or rote learning as a substitute for training. The teacher's role should be a guide, not an authoritarian. However, Zverev admits that this is his hope for the future; it has not been, nor is it currently a common practice.

The image of school as it was perceived by the Soviet people was of an extremely formal classroom atmosphere with much rote learning and a very highly factual content (Muckle, 1990; Richmond, 1992). It was almost entirely teacher centered. Students always stood when the teacher entered the room. They raised their hand to ask a question and stood when reciting or responding to a question. From the earliest grades, students in Soviet schools were taught to think and act collectively, respecting the position and authority of the teacher. Discipline was strict. There was little or no discussion in the classroom. For each question asked by the teacher, there was one correct answer. 
In classifying teaching methods, Zverev (1983) provides a chart indicating numerous teaching methods and how often they appeared in Soviet educational literature. (See Appendix B, Teaching Methods in the Soviet Union). According to Zverev's research, teacher-fronted methodology was most often mentioned in the literature surveyed, with narration, teacher's discourse, lecture, teacher/pupil dialogue, and use of textbooks being the most frequently used teaching techniques. Those methodologies least often addressed in educational literature were student-centered methodologies, such as practical applications, creative oral and written exercises, discussion, and pupils' projects. There was no indication of methodologies that made use of group interactions (pairs, triads, etc.).

The content of education received by every child in any Soviet school consisted of a large core. Central control of the curriculum was almost total. Because Marx and Lenin were adamant in their desire for equal education to be provided for all people, there was not even the remotest possibility that an individual school would be allowed to develop its own curriculum or stray from the state set curriculum. The curriculum was not tailored to the child, but the child was helped to assimilate the curriculum. The State authority insisted that all school subjects which were essential to "harmonious development of all-round personality should be compulsory" (Muckle, 1990, p.58).

Schools of the Soviet era had roots in the Russian past (Richmond, 1992). Schools traditionally were viewed as responsible for the moral upbringing of youth, teaching children moral values of how to behave and relate to society. Uniform 
curriculum and textbooks were a tradition that began in the nineteenth century. A dependence on rote replies and a preference for spoken form of communication were also carryovers from the past. Soviet education continued these traditions and added some new ones.

A significant aspect of the educational system for the Soviet student, with a particularly negative impact for Soviet Evangelical children, was the pressure for all students to belong to the communist youth clubs. In the early grades, the club was the Octobrists; during their third year of school, children were expected to join the Pioneers; and at age fourteen they could join the Komsomol. Peer pressure to join these groups was intense, and the penalties for failing to do so were very harsh. Only members of the Komsomol were allowed to continue their education beyond high school. And only Komsomol members could hope to obtain prestigious jobs which might provide a prosperous living (Richmond, 1993; World Relief, 1989).

\section{CULTURE CONFLICTS IN THE ESL CLASSROOM}

"People tend to think that the learning environment with which they are most familiar is representative of learning environments in general ... Or their environmental images are held up as models for what the learning environment should be like" (Andersen \& Powell, 1988, p.207). Powell proceeds to say that not only do students hold certain expectations for education, but teachers tend to teach the way they were taught. 
A theme that emerges from the discussion of cultural conflicts in the ESL classroom, is that different expectations are often held by teachers and students regarding appropriate classroom behavior and interaction between teachers and students (Anderson \& Powell, 1988; Fitch, 1986; Furey, 1986 ). Students have definite expectations of teacher behavior, teaching methods, classroom manners, and student behavior. In one culture students sit silently in their neatly arranged rows of desks, responding only when recognized by the teacher. In another culture, students have casual friendly relationships with their teachers, walking around the classroom and talking among themselves (Anderson \& Powell, 1988).

Because of the United States government's desire to quickly assimilate refugees, a certain amount of English education is provided immediately upon their arrival in the United States. This often makes the ESL classroom one of the first culture contact settings in which refugees and immigrants find themselves. In the ESL class the 'old' meets the 'new', and the meeting is not always harmonious (Anderson \& Powell, 1988; Furey, 1986; Fitch, 1986 ). For, although they have left their homeland to find religious and personal freedom, refugees and immigrants have not left the cultural imprint of their homeland. There may be much they gladly left behind, but without doubt, there is more they left with sadness. In his book, From Moscow to Mainstreet, Ripp (1984) quotes an older second generation Soviet Jew as saying:

For you, it [Russia] is territory, but for me---it's my homeland. A pity she was not the mother one would have liked, but still she was my mother. A pity that she did not nurture us as one would have liked, still 
she did sustain us. A pity that love and hate for her are mixed, but they are not mixed equally. A PITY. (p. 21)

Adult refugees re-enter the classroom setting with a mental storehouse of how things should be done. Fitch (1996) states that when they encounter an unfamiliar environment, they may be unable to assimilate the differences. They may be horrified or offended by what they consider rudeness or presumption on the part of fellow classmates. They may be confused by the informality expressed by the teacher. It is Fitch's proposition that this confusion and possible sense of powerlessness may result in open or subdued conflict with the teacher. Another possibility, says Hilles, is that the ESL student will simply leave the program. If a class isn't meeting their felt needs to an acceptable degree, they "vote with their feet" and leave (1991 p. 405).

It is also suggested that, while religion is perhaps the least acknowledged, it is the most powerful complicator of communication between persons of different cultures (Smart, 1988). Even people who completely reject religious beliefs are influenced by it. "The final sanctions behind most cultural norms are religious, for the cultural norns are seen as the means toward the ultimate fulfillment of life itself" (Smart, 1988 p.62). Soviet Evangelicals bring their religious as well as their educational heritage and convictions into the classroom. This, too, may be an area of conflict. These convictions may seem odd or unusual to their American teachers. And because of the teachers' training and personal convictions, they may also seem detrimental to the learning process.

Furey (1986) believes that students from societies where there is a high degree of teacher authority and direction, may have a low tolerance for the more casual 
egalitarian teaching methods found in ESL classrooms in the United States. They may have difficulty with activities requiring student choice and initiative. Ripp (1984) again quotes a Soviet immigrant's reaction to American high schools, "Say what you want about the Soviet Union, its terrible ideology and so on, at least it provided good schools" (p. 113).

\section{SUMMARY}

Christians endured decades of persecution in the attempts of Communist leaders to obliterate Christianity from the former Soviet Union. But their Christian faith, which had been rooted for centuries in the heart of Russian culture, did not die out. Rather, believers found refuge, unity and strength in binding together as a group. This strength, which was found in the cohesiveness of a group, was as deeply rooted in the "Russian" culture as was their religious faith. In the group they found not only strength, but they found boundaries that would help define their lives. To cross the boundaries was to step out of the security of the group into territory that was physically, emotionally and spiritually unsafe.

A very significant area of life, which often tested the boundaries of the Christian, was the area of education. The philosophy and goal of education in the former Soviet Union was to develop attitudes of working for the common good. Schools were traditionally thought of as responsible for the moral upbringing of youth. For the Communist teacher, this meant that they were responsible, among other things. for trying to persuade their students in the falsity of religion. 
In order to reach its goals, the government mandated a strictly controlled curriculum. All students in the far-reaching Soviet Union received identical instruction with teachers using identical teaching methods. Teaching methods were entirely teacher-fronted and directed, with the teacher being the ultimate authority in the classroom. Coming from this background, Soviet Evangelicals now find themselves in the tenuous position of refugees, forced to return to school, schools perhaps far different from what they are accustomed to, in order to learn a new language and a new way of life.

It is suggested that in order for ESL to be successful, teachers must examine their teaching methods and classroom practices and compare them with relevant features of their students' cultures (Anderson \& Powell, 1988; Furey,1996). Teachers need to provide explanations and careful guidelines when the methods and practices differ from the students' previous experience. In order for ESL teachers to be able to make such comparisons Furey suggests creating a framework specifying those features that provide a basis for cross-cultural comparison. 


\section{CHAPTER THREE}

\section{RESEARCH DESIGN AND DATA COLLECTION PROCEDURES}

\section{INTRODUCTION}

The purpose of this study was to explore the educational and core values of Soviet Evangelical students. The focus of the study was on understanding their past educational experiences through personal interviews and on understanding their current ESL experiences through classroom observations.

This chapter is divided into three sections. Section one discusses the time frame, research site and the participants involved in the study. Section two gives an overview of the data collection procedures. And section three discusses limitations of the study and recommendations for further research.

\section{RESEARCH DESIGN}

\section{Time Frame}

Field research was limited to one ten week academic term. This time frame provided continuity of observation as well as continuity of subject participation. Because the ESL program in this study did not have an open-entry/open-exit policy, a single term study eliminated dealing with the entrance of new students into the class and the loss of students due to withdrawal. Formal interviews of former teachers from 
the Soviet Union, the administrator of the community college and the ESL teachers in the case study occurred prior to and shortly after the ten week time frame.

\section{$\underline{\text { Research Sites }}$}

(Note: All names and identifying details throughout this report have been altered to insure the confidentiality of the participants.)

This study was conducted in a community college in the Pacific Northwest. The college was selected because of its large Soviet Evangelical (SE) student population. In order to insure the anonymity of the participants in this study, the college will be referred to as Compton Community College and all participants' names will be pseudonyms.

Gaining entry into two classes was accomplished by first contacting the head of the ESL program at the college. After hearing about the nature of the study, he suggested several teachers who might be interested in taking part.

Contact with the first teacher, John, was made initially through a phone call and subsequently with a letter of introduction and explanation of the study (see Appendix C, Letter of Introduction to ESL Teacher). This class was a level 4 multiethnic class that met for three hours a day, Monday through Thursday. There were generally around nineteen to twenty students present on the days of observation, seven of whom were SE students. Written permission was given on the first day of class when we formally met.

A second class site was secured after the first day of the quarter. As a means of obtaining the second site, John introduced me to the other ESL teachers. After 
speaking to them briefly and distributing the letter of introduction and research description, I was invited to observe their classes to see which would best satisfy the needs of the study.

A level 2 class, taught by Carol, was selected as the second class site. One of the main reasons this class was chosen was because, although the students' language skills were basic, some of the students had an English comprehension and communication level that would allow researcher and participant interaction. Also, this class, with its large number of Soviet students, would provide a contrast to the upper level class with a smaller Soviet student population. Carol's class, which was also multi-ethnic, had approximately twenty students from former Soviet countries. There was an average class attendance of about twenty-five students. Written permission for site participation was obtained from the teacher on the first day of observation.

The use of two class sites benefitted the study in several ways. First, there was the benefit of a broader base of Soviet Evangelical students to study. Second, there was the benefit of observing students at multiple levels of language learning. And third, there was the advantage of observing two teachers with their own teaching styles and the students' responses to these styles.

Compton Community College had seven levels of ESL classes: levels 1 and $1 \mathrm{~b}$, level 2. level 3, level 4, level 5, level 6. In level 2 the students should know the English alphabet and have a beginning level of listening and speaking comprehension. By level 4 student should be able to understand English conversation on familiar topics when spoken at a slow speed. They should be able to converse with certain vocabulary 
helps. The ESL curriculum was based on survival skills, not academic skills. As is the nature of much adult ESL teaching, the four elements of language learning (reading, writing, listening, speaking) were interwoven into lessons taught by the same teacher. They were not taught as separate classes, as is more typical in college preparatory ESL classes.

According to the head of the ESL program, Compton Community College had, at the time of the study, an unduplicated registration of $810 \mathrm{ESL}$ students for winter term 1994. Of those students, he estimated that about $50 \%$ to $55 \%$ were from the former Soviet Union. Each class had an official maximum enrollment of 25 students; however, teachers could, at their own discretion, allow a higher enrollment. John kept the enrollment at 25 while Carol allowed a higher enrollment.

Classes at the college ran in three hour shifts from 9:00 a.m. to 12:00 p.m., 12:00 p.m. to 3:00 p.m., and 3:00 p.m. to 6:00 p.m. Most of the classes were beginning levels one and two, with nine level one classes. At the upper end, there was only one level five and one level six class.

The ESL program used a state mandated curriculum which the teachers were able to modify to meet the needs of their students. However, there were basic competencies which the students had to pass before progressing to the next level. Each teacher was expected to write his or her own curriculum, based on the state curriculum; for the four terms of the school year. They submitted the curriculum and lesson plans to the head of the program. At the end of each term the students were 
assessed by the teacher. If there was space available in the next level, and if the students qualified, they were passed on to the next level.

\section{$\underline{\text { Research Participants }}$}

The subjects of this study were Soviet Evangelicals coming from any of the former Soviet Republics. They were all adult students enrolled in and attending ESL classes. Because the researcher did not have a working knowledge of the Russian language, and because of the difficulty of scheduling interview sessions with an interpreter present, it was necessary for the subjects to have a communicative, albeit limited. English speaking ability.

Of the twenty SE students in level II, all were included in the classroom observations and four were included in the personal interviews. There were seven SE students in level IV, all of whom were observed and five were interviewed.

\section{DATA COLLECTION PROCEDURES}

\section{Classroom Observation}

Classroom observations consisted of two methods. On a long term basis, I acted as a participant observer. On a more limited basis, an observation system was used on several occasions to tally numbers and kinds of teacher/student interaction patterns.

Participant Observation. Spradiey (1980) makes a distinction between participant observation and ordinary participation. Ordinary participation occurs when people who are part of a culture setting take part in activities without thinking about the process. A participant observer, on the other hand, has a dual purpose in a social 
setting: (1) to take part in the social activities, and (2) to observe the activities, people, and physical aspects of the situation. The participant observer needs to become explicitly aware of the details of his or her environment, noticing things usually blocked from the awareness of the ordinary participant. Through the use of field notes, made from the observations and interactions, the participant observer discovers themes and patterns that help to explain the culture of the group being investigated.

Spradley points out that there are degrees to which a researcher becomes a participant observer. These range from passive participation to complete participation. Because of the boundaries and limitations of the study, I was able to become a moderate participant in this study. Moderate participation occurs when the researcher maintains a balance between participation and observation, not actually becoming an 'insider', but not remaining totally 'outside' of the group.

During the ten week term, I observed level 2 on nine Wednesdays and level 4 on nine Mondays for a total of 50 hours. While it would have been preferable to observe the classes on different days of the week, personal restrictions mandated these observation times. Typically, I rotated where I sat during the class. Changing my observation point allowed me to be in closer contact with different groups of students. It also provided a variety of vantage points for observing overt and non-verbal communication.

In the level 2 class I was introduced by the teacher as a student teacher who would be in the class on a regular basis. During the course of the term, I was able to explain to the students my research project and how they could be involved with 
helping me. In the level 4 class, the teacher introduced me as a research associate and I was able to explain the purpose of the project at the outset of the course. The teacher in level 4 also asked me to teach several lessons. In both classes I felt that I was accepted by the students as an associate teacher. I interacted with them during classroom activities. Eventually I felt comfortable initiating conversation with the students before class and during break times.

Participant observation begins with the researcher looking at and for a broad range of activity, responses, and physical attributes. Then observations begin to build upon previous observations. In the beginning I observed everything, then gradually began to focus in on particular behavioral, perhaps cultural, features that seemed to emerge. This unfolding of patterns is characteristic of participant observation and ethnography in general (Dobbert, 1982; Nunan, 1992; Spradley, 1980).

Field notes were maintained throughout the research period. During the class sessions themselves, I took notes on my observations. (see Appendix D, Fieldnotes.) On the same day (with the exception of one class session), I wrote up an expanded account of the original abbreviated notes, noting my own responses and reactions to the events of the day, evaluating, summarizing and doing a preliminary analysis of the data.

Observation Analysis System. An observation system was used as a second technique of classroom observation. The advantage of an observation scheme is its ability to reveal patterns and regularities that might otherwise go unnoticed (Nunan, 1989). When used in conjunction with participant observation, it helps confirm or 
negate emerging theories. The system used in this research was not intended to be used as a quantitative measure of specific behavior, but as an illuminator of behavior.

Classroom interactions were recorded using a tally system (See Appendix E, Observation Analysis Tally Sheet). The system was a modified version of a tally sheet shown in Nunan's book, Understanding Language Classrooms (1989). There were nine areas of teacher-related observations and three areas of student-related observations. Teacher/student interactions were observed during three fifteen minute segments of both classes when teachers were asking questions about grammar exercises. The purpose of the tallied observation was to ascertain if there were interaction patterns between the teachers and the students. It was then possible to compare and contrast teacher/student interaction patterns in these ESL classes with past teacher/student interactions patterns as described by the SE students.

During the time that the observation system was being used, I positioned myself in a location permitting a clear view of as many students as possible. The sessions were also audiotaped to help maintain the reliability of the findings. Immediately after class I listened to the tape, checking my original tallies.

\section{Language Learning Preferences Survey}

"It is widely accepted by teachers that such things as ethnicity, age, etc., will have an effect on preferred ways of learning" (Nunan, 1989, p.51). In order to determine if, indeed, there were certain preferences common to the Soviet Evangelical students in the two classes of this study, a language learning preference survey was given to both classes. The survey used was one that was used by Willing in 1988 in a 
large scale study of immigrants to Australia (Nunan, 1989). (see Appendix F, Language Learning Preference Survey.)

In order to prevent the non-Soviet students from feeling slighted, both teachers preferred that the questionnaire be given to their entire class. This required that it be given in English as it was impossible to obtain translations in multiple languages.

Prior to having them complete the questionnaire, I explained its purpose, the fact that it was optional, anonymous and that there were no 'right' answers. In addition to each student having a questionnaire, I displayed one on an overhead projector. Because the questionnaire was written in English, I went over each statement carefully, answering questions, and in the case of level 2 illustrating some of the statements with drawings.

The results of the questionnaire were tabulated by country. Only the responses of the Soviet students are recorded in this study.

\section{Interviews}

Because of the scarcity of documented research on the Soviet Evangelical, and the former Soviet culture in general, many teachers, administrators and case workers must rely on their intuitions based on the behavior of and comments by the students in their classes. In order to hear their own perspectives on the ESL classroom, the value of education, the role of the teacher, and past teaching methods and activities, formal interviews were conducted with nine Soviet Evangelical students. In order to gain insight into the teachers' perceptions of their Soviet students, interviews were also done with the two teachers involved in the study. In addition, many casual interviews. 
in the form of conversations, occurred spontaneously with other students and with other ESL teachers on breaks, and after class.

Werner and Schoepfle (1987) state that the formal ethnographic interview consists of three parts: 1) pre-interview; 2) interview; 3) post-interview. Pre-interview consisted of establishing myself as a part of the classroom. After about four weeks of class participation, I met with all of the Soviet Evangelical students in level 4 as a group. I gave each one a letter of explanation and an informed consent form translated into Russian and asked them to consider being a part of the project. (See Appendix G, Letter of Introduction and Informed Consent). I answered questions and agreed to provide them with some written questions to help them think and prepare for the interview. They were aware that the interview would need to be in English unless they knew of someone who could translate for them. However, each expressed that the experience of using English would be good for them. During the following weeks, I arranged meeting dates with five of the seven students.

The pre-interview process for level 2 was similar to that of level 4 . The difference was that the teacher wanted to select the students to be interviewed. I was agreeable to that as she knew which students. would probably be most interested and able to take part. With this group, I met with five students, one after another, on an individual basis. I gave them the letter of explanation and asked them to consider taking part in the project. One of the students, an older woman of around 75, wanted to take part, but wanted to have her nephew come as an interpreter. Another student, a young woman. seemed very suspicious and said she would need to talk to her 
husband (she later chose not to participate). The rest immediately said they would like to take part in the interview.

Because of the value former Soviets place on the group (Richmond, 1992), meeting openly with the students seemed to 'fit' culturally. In the early part of the study I pondered how to make contacts with individuals. Unlike several Koreans, Japanese and Vietnamese students, the Soviet Evangelicals did not invite me verbally or non-verbally to participate in any outside conversations. Meeting as a group in level 4 and informing a series of students simultaneously in level 2 seemed to eliminate a sense of individuality or secrecy about what was occurring.

The actual interviews were based on a combination of open-ended and closed questions (Fetterman 1989; LeCompte \& Preissle 1993; Werner \& Schoepfle 1987). The first interview acted as a pilot interview in that it pointed out weaknesses in the questions, unnecessary and important avenues of inquiry, and the necessity of establishing a set location for the interview.

The first interview was conducted in an empty classroom at the community college. This proved to be a poor location as we had to move to another room midway through the interview. The next six interviews were conducted in a semi-private "cubicle" which I reserved in the Learning Lab at the community college. The last two interviews (with the two sisters in level 2) turned into a family interview in the home of one of the sisters. In this interview the adult sons acted as interpreters. All the other interviews were conducted in English. 
Because the interviews were conducted with speakers of limited English, an interview guide was used. (see Appendix $\mathrm{H}$, Interview Guide.) As suggested by Patton, an interview guide "makes sure that basically the same information is obtained from a number of people by covering the same material" (Patton, 1990 p. 283). The interviewer, however, remains free to build a conversation within a particular subject area. And in the case of speakers of limited English, I was able to substitute and modify the questioning to the level of ability of the interviewee. The progression of the interview remained basically constant. It began with non-threatening questions about their family and background, then moved on to more in-depth questions soliciting their opinions and feelings.

While the interviews had a sense of formality about them through the presence of a tape recorder and the use of a list of questions, by using the interview guide format, I was able to create a conversational and relaxed atmosphere by allowing the interviewee to direct the course of the interview when it seemed helpful and relevant to the subject. This did not present a problem to completing the interviews on schedule.

The post-interview, on several occasions, turned into a casual interview. After the tape recorder was turned off and we were "just visiting" some very interesting personal information was shared.

The interviews were audio-recorded and in most cases transcribed later that same day. (see Appendix I, SE Student Interview/Transcript Sample.) Those that were not transcribed on the same day were completed within a week. On one occasion the 
tape recorder did not work. In this case, notes were used to reconstruct the interview within a few hours.

In the case of the two women interviewed in level two, I was invited to one of their homes for dinner. The interview became a group interview as three sons and a daughter entered into the conversation, translating and giving their own perspectives on the issues. This session was not recorded, but the comments and topics were written up the same evening.

Chapters four through eight present the data collected and analyzed in this study.

\section{LIMITATIONS OF THE STUDY}

Limitations in carrying out this study included time restrictions. Because it took about three or four weeks to make contacts with the SE students, that left only about six weeks to schedule interviews with nine individuals. Also the personal restrictions on the researcher's time in the classrooms made developing relationships with the SE students a challenge. Conducting a longer study along with being in the class more often during the week would make the interactions with the SE students richer.

A second limitation was the language barrier between the SE students and the researcher. The students said they were glad to have an opportunity to practice their English in the interviews because they seldom used English in conversations with Americans. But their comprehension and communication levels in English limited the 
depth of interaction. A study conducted in their L1 would improve the quality of the interviews.

A third limitation in carrying out the study was the researcher's lack of training in observation analysis systems. However, since the system was not being used in a quantitative way, this limitation did not negate the use of the system. It was used to look for patterns, not to measure specific behavior.

\section{RECOMMENDATIONS FOR FUTURE RESEARCH}

1. Track Soviet Evangelicals from their entrance into an ESL program for five year. Do they change ESL programs? If so, why. How long do they study ESL. What do they do after they finish/drop out of ESL classes?

2. Replicate this study, but conduct interviews in their native language. Are the findings basically the same, or are they significantly different?

3. Focus study on past teaching methods. Seek to discover if Suggestopedia and other methods were used along with the grammar-translation method.

4. Study their cultural adjustments. How do these impact their participation/attendance in ESL classes.

5. Research politeness patterns in their cultures and language. 


\section{CHAPTER IV}

\section{THE ESL CLASSROOM}

\section{INTRODUCTION}

The starting point, in the study of Soviet Evangelicals (SE) as students in ESL. classrooms, is with the people themselves. Chapter IV gives an overview of the two classes, introducing the teachers and the students involved in the study through the use of classroom observations and student interviews. Chapters V though VII describe the phenomemon of Soviet Evangelicals as participants in ESL classes by answering the guiding questions posed in Chapter I: (1) What are the Soviet Evangelicals' modes of learning? (2) What have been the Soviet Evangelicals' classroom experiences in teacher-student interaction patterns? (3) How do Soviet Evangelicals view the teacher? (4) What are the cultural values of Soviet Evangelicals that relate to teaching methods and classroom practice? (5) How do their teachers view Soviet Evangelicals? These questions are addressed through classroom observations; a learning preference survey; and formal and informal interviews with the Soviet Evangelical students, their current ESL teachers, and former Soviet teachers who are now refugees themselves. The study addresses the Soviet Evangelical students' past experiences and attitudes and makes comparisons with current experiences and attitudes. 


\section{LEVEL 4}

\section{The Setting}

The level 4 classroom was large with high ceilings. It looked like a large conference room with educational accessories. There were blackboards on three walls, not traditional blackboards, but the white kind that one must use markers to write with. Bulletin boards with maps of the United States and the world were on the two side walls. A collage of multiple nationalities partially filled one bulletin board. Charts of vowels and letters of the alphabet ran along the top border of the side and back walls. On a bookshelf in one corner of the room was a globe. In another corner, in the front of the room, a TV monitor perched high above the heads of the students. There were no windows, but the room was well lit with overhead fluorescent lighting. The students' desks, which were rectangular tables pushed together in the form of a large $U$, and had the chairs placed along the outside of the $U$ facing in, reflected the teacher's attempts to create a communicative atmosphere in what otherwise would have been a traditional class setting.

\section{The Teacher}

Note: All names and identifying details throughout this report have been altered to insure the confidentiality of the participants.)

That which one first noticed about John was his full gray beard. He had an air of seriousness about him, but at the same time he expressed a dry sense of humor. He seemed both cordial and kind toward his students, but did not encourage sharing 
personal information about either his life or their lives. John did not verbally praise his students often, but frequently nodded affirmatively to give encouragement. And, while he rarely laughed, his sense of humor surfaced in the midst of a lesson. During the lessons John walked around the classroom listening, assisting, and encouraging the students. He wrote on the whiteboard frequently, making use of charts when possible to communicate relationships between concepts. His primary method of teaching on the days of observation combined both communicative and authoritative activities, using the level 4 textbooks as the basis for the course.

\section{The Students}

This level 4 class consisted of individuals from the former Soviet Union, Vietnam, China, Iran, Korea, Honduras, and Japan who had been in the United States from three months to ten years. The class was fairly evenly divided between Vietnamese and Soviet students, with seven from each of these two cultures. The other students included three from Japan and one each from several other countries. The class was heavily outnumbered by female students, with only two Russian men and usually three or four Vietnamese men in attendance. Of the SE students, the two men were very quiet in class. The SE women in the class seemed more involved with the class activities than did the men. They frequently took notes during the teacher's presentation, and during videos. With the exception of one man and one woman, the SE students all had pleasant expressions on their faces, smiling and sometimes laughing with a partner. The two exceptions, while seeming quite somber, were not "unfriendly" when spoken to on a one-to-one basis. They just didn't smile very easily. 
All of the SE students were in the forty to fifty age group with the exception of two younger woman who were about thirty.

The five SE students who participated in interviews were Leonid, Igal, Irena, Svetlana and Tasha. Leonid, a father of eight children, came from Kyrgystan. He was a piano tuner "back home" and was the only student interviewed who had attended a university. At the time of the interview he was a choir director. Although he was unemployed, he had made six violins in his home which he had sold. Each time, he said, the violins got better; he hoped to continue improving his skills and his violins. Leonid, was happy to be in the United States. He did not miss Kyrgystan because life there was too hard. He and his children never knew where the food would come from for the next meal.

Igal, a father of nine, grew up in Georgia, but moved to Siberia for work when he married. He was first a truck driver, but later became a welder. He was now unemployed and had no idea what he would do for an occupation in the United States. He would like to take "regular" classes at Compton Community College when his English was good enough. Beyond that he didn't know. Igal was one of the quieter students in level 4 . While he said that he would like to have more practice speaking English. he didn't initiate conversation during pair and group work.

Irena, a young mother with four children, came from Yelta in Ukraine where her father was a manager in a medical university and her husband was a truck driver. Irena was a very diligent and successful student in level 4. She listened intently, took many notes, participated well with group and pair work. She said that she would like 
to be able to take courses at Compton Community College when she finished with ESL classes. Although her current "occupation" was taking care of her family, her dream was to learn how to fly an airplane.

Svetlana had a small business in Krasmodov, Russia before moving to the United States. She was, at the time of the interview, working part-time at a factory along with taking English classes. Life was difficult for Svetlana. She was a single mother raising three sons, two of whom had recently dropped out of their American high school. Her husband had chosen to stay in Russia when she left for religious reasons. This serious part of her life was not evident in her demeanor in class. She smiled a lot, laughed, and seemed to enjoy interacting with others. One would never guess at the sadness in her life.

Tasha, also a single mother with two teenage sons, left her home in Almaty, Kazakhstan. She left for multiple reasons: religion, economy, to get away from family pressures, and to be near many family members who were already in the Pacific Northwest. Tasha had found the cultural adjustments of being in America very challenging. Small things, like people smiling all the time, were very different. In her country when people smiled a lot it was a sign of mental illness!

\section{The Atmosphere}

With the teacher being of a calm disposition, and the activities being primarily teacher-led and directed, the resultant atmosphere was a reserved quietness. Prior to the teacher's entrance there were usually several pairs of students quietly talking together. When he arrived, he greeted the students and began the lessons right away. 
Student activity was almost entirely done at their own desks, unless the teacher moved students to create mixed groups. There was very little student initiated interaction. They waited for the teacher to ask questions or give directions.

While the students always seemed relaxed in the classroom, it had a definite academic "feeling" about it. One student referred to the class as being "a usual" class, as compared to other ESL classes that were "more interesting".

\section{LEVEL 2}

\section{The Setting}

This level 2 classroom was physically identical to the level 4 classroom. The only difference was in the seating arrangement. The "desks" in this class were large round tables with six chairs placed around each one. Four, or sometimes five, students sat at each table, all facing the teacher as much as possible. On one of the bulletin boards were picture displays of two sets of siblings who were students in this class. Under each picture was a typed description of the students, telling where they were from and a few interesting pieces of information about their backgrounds.

\section{The Teacher}

Carol was a contrast to John in a number of ways. She smiled a lot, laughed quietly, and didn't hesitate to talk about her family and her personal life. She invited her students to share their opinions, but she wasn't hesitant to disagree with them when their values differed from her own. Sharing openly with the class and talking 
freely about tolerance, acceptance, and different values was her attempt to help the SE students adapt to the diversity they would find in the United States.

During the lessons Carol walked around the room speaking with students, encouraging, correcting, and frequently praising them for their work. Her primary method of instruction was communicative with the inclusion of some authoritative work, because the students "wanted it." Her opinion of teacher-fronted classrooms was that they were a "dead-end". This philosophy of language learning was evident in the kinds of activities she wove into her lessons. A frequent student task was a 'human bingo" type of activity, the goal being student initiated interaction with other students.

\section{The Students}

Of the approximately thirty students in this class, twenty were from the former Soviet Union; ten were from Vietnam; and one student was from China. While there was less cultural diversity in level 2 than there was in level 4, the age span was greater, with students in their early twenties to mid-seventies. The majority of SE students, however, were in their thirties and forties. There were several SE family units in the class: two sisters, one about seventy-five years old and the other about fifty-five years old; two brothers in their thirties; and one married couple in their thirties. The class was fairly evenly divided between men and women. While the SE women would quietly answer questions directed to the class and talk among themselves at their tables, four or five of the SE men dominated the class by consistently calling out answers, asking questions, and talking not only to those at their 
table, but often to students at other tables as well. At the same time, there were other SE men who rarely spoke out at all.

The four level 2 SE students who participated in interviews were Andrei, Marina, Olga and Ivan. Andrei, a young father of three children, came from Vinnigsa, Ukraine. He had a very out-going, pleasant personality. In class, he was one of the students who wanted to answer all the questions and didn't hesitate to ask questions. He smiled often, interacted with the teacher and talked easily to his classmates, both Soviet Evangelicals and other nationalities. Though Andrei received training in the Celebration Army to be a bricklayer, he didn't know what he wanted to do in the United States. He commented that some of his friends were getting jobs as truck drivers, a good job in Ukraine, but which be was beginning to think Americans thought was a "bad job". Andrei was very happy to be in the United States. In Ukraine, he and his wife had a room in his parents' home. America, he felt, would be a good place to raise his children.

Ivan, a father of seven, came from a city in the Caucasus Mountains in Russia, where he and his brother (also a student in level 2) had an interior decorating business. Unemployed at the time of the interview, Ivan was the pastor of a pentecostal Seventh Day Adventist church that met in his home. Ivan was a very out-going, animated, and sometimes overbearing person. Being one of the most outspoken students in class, he often was corrected by the teacher for "talking out" and for using his native, or "first" language (L1) rather than English. His assessment of the United States was that it was better than Russia. It was much safer here, he said, because the police were more 
dependable; and there was more freedom. He felt that America was better for his children because the schools were better and more interesting than schools in Russia.

Olga and Marina were sisters. Marina, the older at seventy-five, never had children, but raised her youngest brother as her son. She had lived in a number of cities in Russia, the most recent being Leningrad (St. Petersburg). Her favorite home was in Siberia where she and her husband loved to cross country ski, hunt, and grow wonderful tomatoes. Olga was a quiet student in class, but always had a pleasant smile and a warm handshake. She faithfully completed her homework and reviewed the day's lessons at home. She said that when others asked her why, at her age, she attended English classes, she told them that it was a place to meet people; and she would say that one was never too old to learn. Of the two sisters, she described herself as the one who could speak English better, but her sister was better at grammar, knew more words and could write English better.

Marina had six children, from seven to thirty-two years old. The three older sons all had university educations in Rostov, Russia. Her family dispelled the stereotype of the "Soviet Pentecostals". The oldest son, was a former engineer in Russia; her next oldest son dressed like a "yuppie" and was studying to be an interpreter; and her third son, with a full beard and ponytail, wore blue jeans, boots, and jean jacket. He was an interpreter until he could begin his own car business.

\section{The Atmosphere}

With a teacher who invited and encouraged class discussion and dialogue, and with a significant number of outgoing and interactive students, the level 2 class was a 
high energy class. There was a sense of comraderie among many of the SE students. Conversations, during group work, sometimes turned to what someone had done over the weekend, with laughter shared over something good that had happened.

While this openness and willingness to talk promoted a sense of good will among the SE students, at times it also got out of control. Carol expressed some frustration with the amount of L1 spoken, and with the dominance and what she considered rudeness of the SE students in general.

\section{SUMMARY}

This chapter has provided an overview of the make-up and personality of the two classes that participated in the study of Soviet Evangelical students in ESL classrooms. It was seen that the two ESL classes shared some commonalities. Both classrooms had the same physical characteristics, with the exception of the seating arrangement; both teachers used a variety of communicative and authoritative activities; and both classes had a multicultural student population.

There were also some obvious differences between the two classes. First, one class was comprised of a large majority of SE students and in the other class they made up about one-third of the student body. The second significant difference was in the students' participation and interaction patterns. One class had an air of reserved quietness, and the other an air of energetic dialogue. 


\section{CHAPTER V}

\section{CULTURAL FRAMEWORK: CULTURE IN THE CLASSROOM}

\section{INTRODUCTION}

Having been introduced to the participants in the research study in Chapter IV, Chapter V addresses research questions one and two: "What are the Soviet Evangelicals' modes of learning?" and "What have been their classroom experiences in teacher-student interaction patterns?" The two questions are combined because, as Furey 1986) points out, "the patterns of interaction that characterize a class are partly related to cultural features such as preferred modes of learning and attitudes toward the teacher" (p.23).

First, an assessment of a learning preference survey shows how the SE students say they like to learn: what kind of activities they enjoy, how they like to participate, and what teaching methods they prefer. Next, the results of the survey and what the SE students said in interviews about how they like to learn are related to and compared with both their past classroom experiences and their present classroom experiences. Finally, patterns of interaction between the SE students and their ESL teachers are examined. 


\section{MODES OF LEARNING}

As Hall (1966) points out, people raised in different cultures learn to learn differently. Some cultures stress rote and memory, others stress demonstration and participation. Some cultures encourage inductive reasoning, while others favor deductive reasoning. However, it is also known that not all learning preferences are culture-distinctive (Nunan, 1989). Much of how one likes to learn is based on individual preferences as well.

On two separate days, the SE students in both classes participated in a survey entitled "How Do You Like to Learn Best?" in order to determine their preferred learning methods. The results of the survey, as seen in Table I, show that some teaching/learning methods were definitely preferred by almost all of the Soviet Evangelical students in both classes; some methods were not liked or only liked a little in both classes; some methods were highly preferred by one class but not the other; and there were some methods for which there was no consensus.

Those ways of learning English that were considered "good" or "best" in both classes were: "I like to learn in class" by reading, by conversation, by writing everything in my notebook, by having my own textbook, by studying grammar, by learning many new words, by practicing sounds and pronunciation. "I like my teacher" to explain everything to us, to help me talk about my interests, to tell me all my mistakes. "At home I like to learn" by studying English books. 


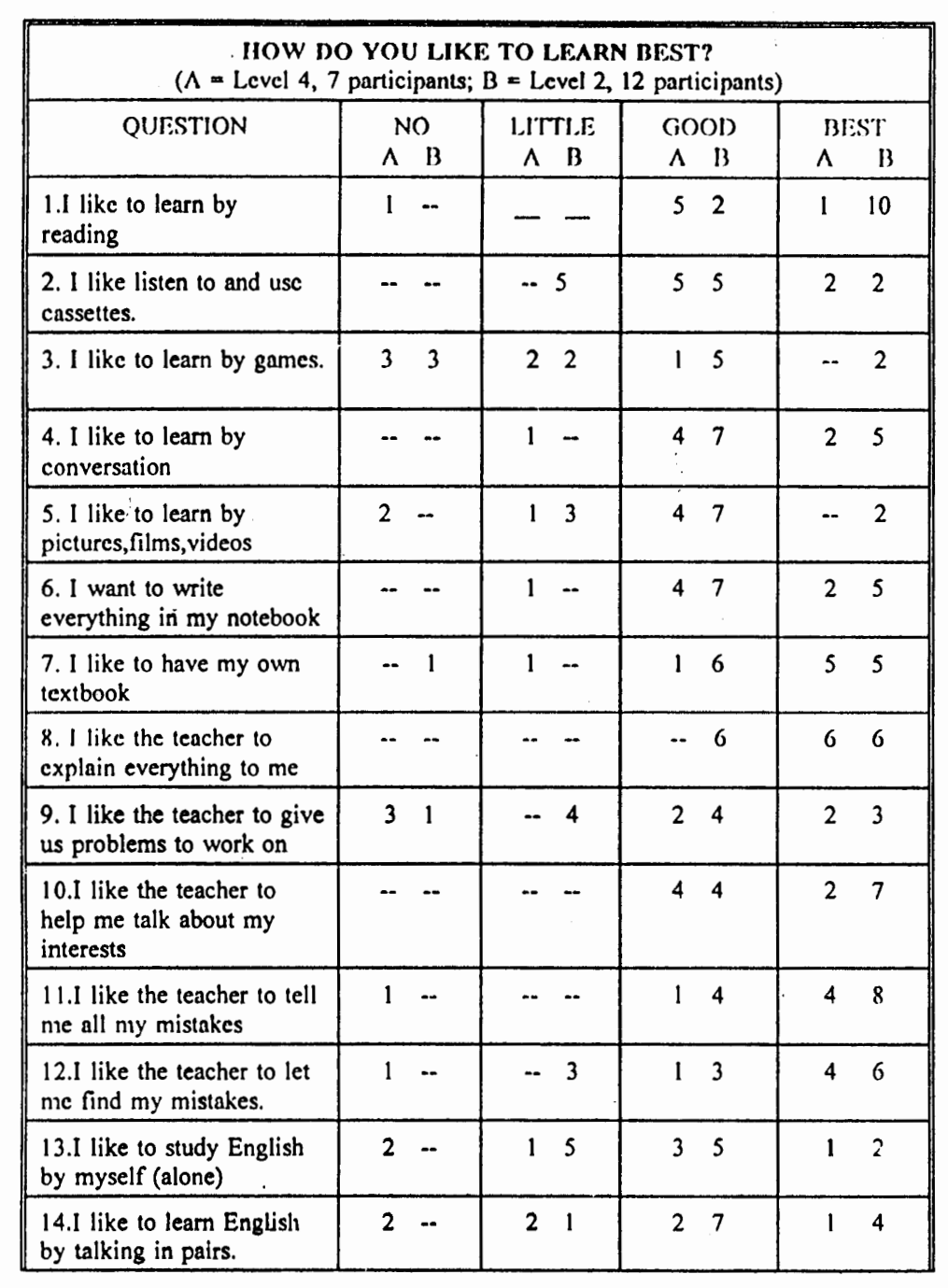

\begin{tabular}{|c|c|c|c|c|c|c|c|c|}
\hline \multicolumn{9}{|c|}{$\begin{array}{c}\text { HOW DO YOU LIKE TO LEARN BEST? } \\
\text { (A = Level 4, } 7 \text { participants; } B=\text { Level } 2,12 \text { participants) }\end{array}$} \\
\hline $\begin{array}{l}15.1 \text { like to learn English } \\
\text { in small groups. }\end{array}$ & 1 & & 3 & 2 & 3 & 2 &.- & 7 \\
\hline $\begin{array}{l}\text { I6.1 like to learn English } \\
\text { with the whole class. }\end{array}$ & 1 & & 2 & 2 & 4 & 7 & -. & 2 \\
\hline $\begin{array}{l}\text { 17.1 like to go out with the } \\
\text { class and practice English. }\end{array}$ & 1 & 1 & 2 & 5 & 3 & 5 & 1 & 1 \\
\hline 18.1 like to study grammar. & 1 &.- & -. & $-\cdot$ & 1 & 4 & 5 & 8 \\
\hline $\begin{array}{l}19.1 \text { like to learn many } \\
\text { new words. }\end{array}$ &.$\cdot$ & 1 & .. & -. & 4 & 5 & 7 & 6 \\
\hline $\begin{array}{l}20.1 \text { like to practice the } \\
\text { sounds and pronunciation. }\end{array}$ & 1 & & -- & 1 & 4 & 2 & 2 & 9 \\
\hline $\begin{array}{l}\text { 21.I like to learn English } \\
\text { words by seeing them. }\end{array}$ & .. & -- & -- & -- & 2 & 3 & 5 & 8 \\
\hline $\begin{array}{l}22.1 \text { like to learn English } \\
\text { words by hearing them. }\end{array}$ & 1 & .. & 1 & 1 & 4 & 4 & 1 & 7 \\
\hline $\begin{array}{l}23.1 \text { like to learn English } \\
\text { words by doing something. }\end{array}$ & 1 & 1 & 1 & 3 & 52 & 2 & -. & 6 \\
\hline $\begin{array}{l}24 . \text { At home, } 1 \text { like to learn } \\
\text { by reading newspapers, }\end{array}$ & - & - & 2 & 7 & 33 & 3 & 2 & 2 \\
\hline $\begin{array}{l}\text { 25.At home, } 1 \text { like to learn } \\
\text { by watching TV in } \\
\text { English. }\end{array}$ & 3 & 4 & 3 & 3 &.. & 4 & 1 & 1 \\
\hline $\begin{array}{l}26 . \text { At home I like to learn } \\
\text { by using casscttcs. }\end{array}$ & -. & -- & 3 & 3 & 2 & 5 & 2 & 4 \\
\hline $\begin{array}{l}\text { 27. At home, } 1 \text { like to learn } \\
\text { by studying English books. }\end{array}$ & -. & -. & - & .. & 3 & 6 & 4 & 6 \\
\hline $\begin{array}{l}28.1 \text { like to learn by } \\
\text { talking to friends in } \\
\text { English. }\end{array}$ & -. & -. & 2 & 4 & 4 & 3 & 1 & 5 \\
\hline $\begin{array}{l}29.1 \text { like to learn by } \\
\text { watching/listening to } \\
\text { Americans. }\end{array}$ & -. & $-\cdot$ & .. & 3 & 3 & 4 & 4 & 4 \\
\hline $\begin{array}{l}\text { 30.I like to learn by using } \\
\text { English in stores/buses,etc. }\end{array}$ & 1 & 2 & 3 & 3 & 3 & 5 & .. & 2 \\
\hline
\end{tabular}


Using the four types of learners designated by Willing (Nunan, 1989), the Soviet Evangelical students' responses showed them to be highly 'authority-oriented' learners. However, the fact that many wanted to learn in class by conversation and by having their teachers help them talk about their interests, showed that they also had some characteristics of 'communicative' learners.

The students in the two classes differed somewhat in how they best liked to learn. At least nine of the twelve students in Level 2 liked to learn English by talking in pairs and learning English in small groups, both of which are 'communicative' learning preferences. This was quite different from the students in Level 4, in which four of the seven students said they did not like, or only liked a little, learning in small groups and talking in pairs.

Students in Level 4, on the other hand, liked listening to cassettes in class, reading newspapers at home, talking to friends in English, and watching and listening to Americans. All of these methods, except reading newspapers at home, which is analytical, are 'communicative' preferences. So it appears that both classes, while having strong 'authoritative' learning preferences, also valued some communicative teaching and learning methods as well.

The Soviet Evangelical students in the two classes agreed in their dislike of learning English at home by watching television. However, in level 4 six out of seven said 'no' or 'a little' to the use of television at home, compared with seven out of twelve in Level 2. Level 2 students did not like to learn English at home by reading the newspaper, which Level 4 students enjoyed. Level 4 students expressed dislike for 
learning English by playing games while Level 2 was split, with seven liking games and five not liking games.

In summary, according to what the Soviet Evangelical students said about their personal learning preferences, they are primarily 'authority-oriented' learners. Authority-oriented learners prefer the teacher to explain everything. They like to have their own textbooks, to write everything in a notebook and to study grammar. They like to learn by reading; and they like to learn new words by seeing them. While primarily authoritative-oriented learners, SE students also had some .'communicative' learning preferences, though these preferences varied somewhat between classes. Communicative learners like to learn by watching and listening to native speakers, talking to friends in English and participating in conversations. Communicative learners also like to learn by watching television in English and using English out of class in shops, which the SE students in both classes said they did not enjoy.

\section{INTERACTION PATTERNS AND ACTIVITIES IN A SOVIET CLASSROOM}

Personal interviews revealed that SE students learned from a strictly regimented core curriculum and most experienced tightly controlled classrooms. It is also important to know what kinds of teaching activities were commonly used by the teachers. because the communicative activities so frequently used in the United States may be thoroughly unfamiliar to students from systems emphasizing rule learning, translation, and memorization (Furey, 1986). ESL teachers need to know if they have 
students in their classes who have never participated in role play, group problem solving, class discussion, and individual choice.

Probably because the central government of the Soviet Union had a structured curriculum that all teachers followed, the responses from the students during interviews all reflected agreement about how teachers conducted class sessions in general. After the teacher entered the room, he or she began immediately with review of homework. Questions regarding homework were posed to one student and then another. Students did not respond spontaneously, but raised their hands for permission to speak. Sometimes the homework review was not question/answer, but the student(s) would repeat for the teacher the information they had read the night before. After the homework material was sufficiently reviewed, the teacher began to lecture on new material. At this point students wrote notes on everything the teacher said. Often the teacher would write on the board and the students copied what was written. Student participation included responding to questions, doing exercises on the board and writing information in notebooks.

Language classes followed the same basic routine as the other classes in terms of teacher-student interaction patterns. Although the SE students could not identify the philosophy of language learning adhered to by their teachers, their descriptions of teaching activities and methods fit the grammar-translation method. Reading activities included reading from a text and translation of the text. The students learned many new words every day and were tested on the words the following day. Dictation was also a regular activity in foreign language classes. Speaking the foreign language 
occurred only in the teacher-student dialogues. None of the students had ever practiced speaking the language in groups. Pair-work consisted of repetition of structured questions and answers. Teachers never used games in class as a teaching method. Most of the SE students interviewed said that they did not enjoy their foreign language classes and laughed at the idea that they had 'studied' English.

Although the SE students may not have enjoyed their language classes, they approved of many of the methods and activities their teachers had used and would like to have them incorporated into ESL classes. On the day the students took the learning preference survey, Nicolai, a SE student in level 2 who apparently dropped the class mid-way through the term, approached me after class and wanted to show me his class notebook. Looking through the notebook and listening to him describe his English class, it was possible to get a "snapshot" of how his class had been conducted. The notebook was beautifully handwritten and organized. It had charts and columns of words with their equivalent Russian words. It looked like a grammar text, a grammar translation text, and a "learn English phrases" text combined in one. Nicolai was visibly proud of the notebook. He said that the information was written on the board by the teacher and that he copied it down.

Then he explained how the teacher taught English vocabulary. The teacher put ten to twenty new words on the board every day. Then he put on music. The students were to concentrate only on memorizing the new vocublary words. After a short period of time. the teacher read and the students either listened or read along in their own texts to a story using the new vocabulary. The teacher then asked the students 
questions about what they read. The students next paired up and asked each other the same questions. This SE student lamented that his ESL class was not taught in this same manner.

The method explained by this student sounds like a modified version of suggestopedia, an approach to language learning developed by the Bulgarian psychiatrist-educator Georgi Lozanov. The use of music and memorization of words is a central aspect of suggestopedia. It is a teaching method that requires the teacher to have great authority. The teacher-student relation becomes like that of a parent to child (Richards and Rodgers, 1992).

Along with liking to learn many new words, the SE students also thought that dictation was helpful. They said they liked for ESL teachers to use it in their classes. They felt it was good for listening comprehension and for spelling.

The most empathically stated request came from Ivan, the most "outspoken" student in level 2, but it was confirmed by several other SE students. Ivan wanted the students to have their own text books and to use them. He expressed frustration that after he had purchased the text for his class the teacher rarely used it. He thumbed through the book and pointed out three or four lessons that the class had completed. But as he flipped from page to page, he said, "I don't know this. I have this text, why? We never use this book" (2/23). He said he would like the teacher to use the text as the basis for the class. He would also like the teacher to explain new concepts and words to the students every day. He felt that the students should work through the text. read the text, and then be able to ask the teacher for clarification the following 
day. Ivan felt that if a text were used as the basis of the course, when students completed the class they could look back at their text and feel good about what they had learned. The indication was that he now had nothing tangible from his ESL class to encourage him in his progress.

Andrei, also a student in level 2, commented that he liked it best when the ESL teacher asked each student to repeat after her. He believed that the teacher should make sure each student was asked to respond to a question. By doing this, he said, the teacher demonstrated that he or she truly cared for the students:

Probably, [my] first teachers [said to] every student, "Repeat after me, please. Remember? Okay, next student. Remember? Are you remember? Yes. Next student." Every student, you know. (3/7)

He did not think questions directed to the whole class were as effective a teaching method as questions directed to individuals. Classroom observations showed that Andrei. while wishing for individual questionning, was one of two students who answered the majority of class directed questions.

In summary, SE students' foreign language-learning experiences in the classroom in the former Soviet Union were clearly authority-based and teacher-fronted. Interaction patterns were teacher-directed questions to specific students. There was no student choice and no 'communicative' dialogue back and forth between students. Teachers followed the grammar-translation methodology which emphasized reading, memorization of vocabulary and grammar rules, and translation of material in the text. However, it is possible that other methods based on high teacher authority, such as suggestopedia, were also used in the Soviet Union. While the SE students said they 
had not enjoyed or learned much in these past foreign language classes, their preferred modes of learning, as noted in the results of the survey, remained primarily authoritybased.

\section{ACTIVITIES AND STUDENT PARTICIPATION IN ESL CLASSES}

In light of their previous educational experience and how they said they like to learn English, it was enlightening to observe the SE students' participation in a variety. of ESL classroom activities. As might be expected, some class activities elicited positive responses while others appeared to be less effective.

\section{Activities and Participation In Level 2}

The level 2 teacher stated that in her opinion "communicative language learning is the only way to teach." The activities she used in her teaching confirmed this philosophy. During the nine three hour observation sessions, the students did three 'human bingo' type activities, two activities in which they needed to locate a partner or a group that had matching picture cards, and numerous activities in which they were to work with a partner. The partner-activities included determining the chronological order of a set of pictures depicting a story they had just listened to, composing sentences, using handouts to interview one another, and working together on grammar activities.

Human bingo type activities, and activities in which the students need to locate a partner or group require participants to get out of their chairs, move around the room and initiate conversation. SE student participation in these activities varied. In the 
student interviews the SE students referred to this kind of activity as a "game". Two previous students of Carol's said that they did not like this kind of game. The current students in Carol's class gave mixed responses in the survey to 'playing games'. This mixed response was evident in the various degrees of participation and enthusiasm observed. During one such activity Carol distributed a deck of cards. The students were to form groups by finding the other three ' $2 \mathrm{~s}$ ', for example. "I don't play cards", one student stated. "It's okay," Carol replied. "These cards aren't for playing. It's not poker."

It was always necessary for the teacher to direct the students several times to get up and move around the room. Even then, not all of the students participated. Some SE students sat at their table talking only to those who also sat at that table or who approached them; some frequently lapsed into their L1; and some willingly took part in the activity and seemed to enjoy it. On one occasion I sat down next to Alex. He was a student who consistently seemed reluctant to participate in these activities. I discovered that he didn't understand the vocabulary. After spending some time with him I moved on to talk with another student. As I looked across the room I saw Alex walking next to the chalkboard toward the door, not as though he were going to ask someone a question, but more like he was trying to find a way out of the room.

During these activities a lot of verbalizing occurred. Students mingled, laughed, spoke both English and their L1. The teacher mixed with the students and allowed them to ask her the questions on the handout. This type of activity usually 
lasted about twenty minutes and Carol frequently fashioned from it a grammar activity later in the day.

Another common communicative activity used in Carol's class was pair-work. or partner activity. For several reasons, pair work was not particularly effective in promoting the use of English with this group of students. First, because this class was largely Russian speaking, it was difficult for the teacher to monitor the use of L1. When the partners were both Russian speakers, their L1 was used during much of the activity. Second, when the partners were a mixed language pair, participation did not always occur. For example, table one usually had the same four students every day, a SE husband and wife and two Vietnamese women. During a pair-activity the wife and one Asian woman were a pair and the husband and the other woman were a pair. They were supposed to put a set of pictures in chronological order. Neither pair willingly spoke to one another. They looked at their papers, looked around the room, and began numbering the picture sets independently. Both the teacher and I, unsuccessfully, tried to encouraged them to work together.

Along with these activities that definitely fit within the communicative teaching method, Carol included some activities that would be considered authoritative. She made dictation a regular component of her weekly lesson plans. She said that all of the students, particularly the SE students, wanted her to give dictations. "They love it. they are asking for it!," she said. This is consistent with their own statements of how they like to learn. Student response to this activity was very positive. The students were attentive to the teacher and they followed along with her to the completion of the 
activity. One day, after completing a dictation, she asked the class if they would like to have a second one this week. The response was nodding of heads and, "Yes, yes, dictation good."

While the emphasis in this level 2 class was listening and speaking, Carol also included a writing project in which the students wrote short poems about themselves. She then put the poems together in a kind of class newsletter. Other activities included listening to tapes, watching a video, grammar lessons, and class discussions. The most obvious way the students in this class signalled if they were participating in a given activity was verbal interaction either with the teacher or with a partner. The most frequent non-participation signals were talking to neighbors in their L1, and working alone when they were supposed to be working with a partner. None of the students indicated boredom with the activities or material by yawning or gazing around the room.

\section{Activities and Participation In Level 4}

In contrast to the emphasis on speaking found in the level 2 class, John viewed the curriculum in level 4 as grammar-based and placed a greater emphasis on reading and writing, incorporating grammar into these skill areas. On the days of observation, the lessons were primarily taken from the Level 4 text books. John viewed the students in this level as serious students who were in class to learn English academically:

By the time they get this far, the ones who hope they can learn English in 30 days are no longer here. Level 4 is pretty academic and prepares the students who want to go on to Compton Community College. By 
the time they get to level 4, many of the Soviet students have gotten jobs and are no longer in ESL classes. (Field notes 1/24)

There was definitely a more academic 'feeling' in this class as compared to the level 2 class. One of the primary reasons for this was the kind of activities incorporated into the lesson plans. Unlike level 2, the human bingo-type of activities, which necessitated students moving around the room and often asking personal questions, were not used in this class. However, mixed language groups were formed on three occasions for the purpose of role play, discussion groups, and making cultural comparisons. Student participation in these group activities seemed high. The role play was simply a matter of reading lines of a dialogue and switching roles; the discussion group and making cultural comparisons required more skilled communicative speaking.

The SE students seemed to enjoy these group activities, particularly the more communicative activities. Within the groups, the SE students made eye contact with other group members; most of the SE students smiled at various times; and a few of the SE students laughed.

A second communicative activity used in the level 4 class was pair work. With many of the assigned grammar lessons, John either directed the students to work on, correct or compare their answers with a partner; or he gave them the option of doing so. As with the students in level 2, pair work did not appear to be very effective in promoting the use of English between students when it was a matter of working together on an assignment. While use of L1 for the Russian speaking students was not as much of an issue in this class, as they made up only about one-third of the students. 
the issue of students initiating conversation with a work-partner was a factor. As in level 2, students chose to work alone when told they could or should work with their neighbor. Sometimes, when this happened, John would walk around the class and quietly tell the various pairs of students to work together. This was effective most of the time, but not always.

When the pair activity was specifically for the purpose of practicing English, however, most of the SE students participated quite willingly, though a few of the SE students seemed to have a difficult time carrying on a conversation in English with a partner. During one of these activities, when one of the SE men and an older Vietnamese man were not talking together at all, John gave each man the task of going from person to person to take a 'survey' based on the content of the material being discussed.

The high level of participation in groups and pair work that were designed specifically for conversation was not consistent with what the level 4 students indicated on the language learning preferences. Four of the seven responded that they did not particularly like learning in pairs and groups. However, in the interviews, four of the five students said that they need more "life-speech" in the classroom; that they would like to have more practice speaking. The low participation level for pair work that was unstructured, such as working together on grammar and other textbook assignments, is more consistent with the results of the language preferences survey.

Other activities used in level 4 included watching videos, listening to tapes. doing dictation, writing paragraphs, writing letters, reading newspapers, and reading 
warranties. Interwoven through all of these activities was the study of grammar. Most of the activities in the level 4 class resembled teaching activities from their past experiences and could be considered authority-based. These authority-based activities appeared to have a high degree of student participation.

In conclusion, both teachers used a combination of communicative and authoritative activities to achieve their purposes of ESL instruction at two different levels. The level 2 teacher emphasized speaking and listening skills with a greater reliance on communicative activities. The level 4 teacher emphasized grammar skills incorporating reading and writing along with communicative activities. Student participation in the communicative activities varied from low to high within each class. depending on the particular activity, while the authoritative activities had a consistently high student participation level in both classes.

\section{TEACHER-STUDENT INTERACTION PATTERNS IN ESL CLASSES}

Teacher-student interaction patterns often are the product of teachers' personalities, teaching styles, and the teachers' educational goals for a particular group of students. These patterns of interaction also play a major part in creating class atmosphere. The ESL classes in this study provide excellent examples of two teachers with different styles of teaching that result in strikingly different teacher-student interaction patterns. These interaction patterns are divided into three areas based on classroom observations: patterns of class discussions; patterns of presenting teaching material: and patterns of question/answer sessions. 


\section{Class Discussion}

In Level 2, Carol used open class discussion to share her personal values with the class with the goal of helping the Soviet Evangelicals understand the diversity of values they face in America. On several occasions students initiated discussions by asking her questions either about herself or about something of interest to them. One day she asked them if they had watched the President's State of the Union address the night before. This led to a class discussion on the merits of President Clinton. These discussions became quite interactive, leading to not only teacher-student interaction, but also student-student interaction. As might be imagined, as the students began to interact with each other, they frequently lapsed into Russian. Carol reminded them, sometimes forcefully, that they needed to use English, not only because they were in English class, but also because not everyone in the class understood Russian. At one point in the midst of a class discussion in which an extreme amount of Russian was being spoken, with one man speaking across the room to another man, and small groups of students talking together, she said, "I've totally lost it here." But the students seemed to be having a good time.

In Level 4, on the days of observation, John did not use class discussion as part of his teaching method. He used, instead, teacher presentations, or, as on one occasion. an audio-tape, to introduce different aspects of American life or culture. He did not invite. either verbally or non-verbally, the students to ask him questions about his personal life and interests, which was consistent with his philosophy of teaching. The presentations were part of the lesson planned for the day. First he talked about the 
subject, then he invited questions, then he frequently often had them form small mixed-language groups. He provided either a handout or they used textbook questions to guide their interaction.

\section{Presenting Teaching Material}

Another type of teacher-student interaction occurred in the presention of teaching material. Grammar lessons were the most common times when the two teachers presented teaching points. In level 2 , the grammar lessons usually came out of a preceding activity, such as a human-bingo type of activity. On these occasions the teacher had the students write self constructed sentences on the board based on their answers to the "bingo" questions. She then read through the questions with the class, correcting as needed and explaining the grammar. During these lessons many SE students initiated questions. It was more of a grammar discussion than a teacher-led presentation.

On several other occasions the level 2 teacher gave about a ten minute explanation of a grammar point. During the explanation she was often interrupted with questions and comments, which again turned the teaching time into more of a granmar discussion than a teacher presentation. At the completion of the teaching time. the teacher assigned either individual or group work to reinforce and provide practice with the grammar.

The level 4 teacher had more definite boundaries to his grammar presentations. The presentations were about fifteen to twenty minutes long, during which he asked the students if they had questions. Some of the Asian students would ask questions at 
that time, but none of the students initiated questions during the grammar presentations. A few students, generally not the SE students, would ask questions for clarification after the presentation. During the presentation the teacher wrote on the board. often making charts to help clarify grammatical relationships being taught. Most of the SE students copied the teacher's examples and charts from the board. When the teacher was finished with his presentation, he frequently had the students divide into pairs to work on an assignment together.

\section{Patterns of Question/Answer Sessions}

Teacher questions/student answers in level 2 followed uniformly the same pattern during the days of observation. The pattern was "captured" in the observation analysis system used to chart teacher/student interactions. As can be seen in Table 2, the SE students initiated more questions/answers/comments in the coded period than did the teacher. The SE students heavily dominated the student interactions, with almost no non-SE students' verbal participation. The teacher asked primarily display questions addressed to the whole class, with only a few referential questions to individual students.

Teacher question/student answers in level 4 followed several patterns. However. the coded periods show only one pattern. A pattern not shown in the analysis system was the teacher asking questions addressed to individual students, not to the whole class. This pattern was usually employed when questions addressed to the whole class brought about little or no responses. However, the level 4 teacher more frequently tried to use the pattern shown in the coded analysis. 
As can be seen in Table II the teacher/student interaction was primarily teacherinitated questions, with more teacher questions than student responses. There were very few student questions directed to the teacher.

There are definitely limitations to the accuracy of this type of coding system. It does not show the actual dialogues that occurred or how many different students took part in the interaction, and it focuses on frequency, not quality. However, the value of the system, is that it does show a pattern. In level 2 the pattern fits with the other types of teacher/student interaction patterns. The SE students took a lot of initiative during the question and answer session, and they were not hesitant to ask the teacher questions, to speak with other students, and to answer questions.

In the level 4 class, the pattern was consistent with the more reserved nature of the class. The SE students did not take a lot of initiative in participating in teacher/student interactions. They responded, however, when the teacher initiated the interaction.

\section{SUMMARY}

This chapter has addressed the questions of Soviet Evangelical students' preferred modes of learning and their experiences in teacher/student interactions. It was seen that SE students preferred teaching styles and activities that were primarily authority-based, such as having the teacher explain everything, learning grammar and writing everything in their notebooks. This concurred with their past educational experiences in Soviet classes, which were highly authoritarian and teacher-fronted 


\section{TABLE II. TEACHER/STUDENT INTERACTION PATTERNS}

\begin{tabular}{|c|c|c|c|c|}
\hline \multicolumn{5}{|c|}{$\begin{array}{l}\qquad(\mathrm{A}=\text { Level } 4 ; \mathrm{B}=\text { Level } 2) \\
\text { (Total numbers of three } 15 \text { minute segments per class) }\end{array}$} \\
\hline INTERACTIONS & $\begin{array}{l}\text { SE Students } \\
\text { A B }\end{array}$ & $\begin{array}{c}\text { Other students } \\
\text { A } \quad \text { B }\end{array}$ & $\mathrm{Cla}$ & \\
\hline Teacher asks display question & --4 & -- & 35 & 33 \\
\hline $\begin{array}{l}\text { Teacher asks referential } \\
\text { question }\end{array}$ & --4 & -. -- & 2 & 6 \\
\hline $\begin{array}{l}\text { Teacher explains grammatical } \\
\text { point }\end{array}$ & --5 & -- & 3 & 7 \\
\hline $\begin{array}{l}\text { Teacher explains meaning of } \\
\text { vocabulary item }\end{array}$ & 22 & -- & 10 & 7 \\
\hline $\begin{array}{l}\text { Teacher explains functional } \\
\text { point }\end{array}$ & -- & -- & -- & 1 \\
\hline $\begin{array}{l}\text { Teacher explains point relating } \\
\text { to content of lesson }\end{array}$ & -- & -- & 4 & -- \\
\hline Teacher gives instruction & -2 & -. $\quad--$ & -. & 3 \\
\hline Teacher praises & -1 & -. $\quad--$ & -- & - \\
\hline Teacher criticizes/corrects & -5 & $--\quad--$ & -- & -- \\
\hline Student asks question & 115 & 3 & -- & - \\
\hline Student answers question & $5 \quad 49$ & 14 & -- & - \\
\hline Student talks to others in $\mathrm{L} 1$ & $4 \quad 13$ & $1 \quad--$ & $\ldots$ & - \\
\hline
\end{tabular}

emphasizing rote learning and memorization of facts as presented in the texts.

Howerer, the SE students also said that they liked some communicative activities as well, such as learning in class by conversation and having their teachers help them talk about their interests.

The teachers in this study used a combination of communicative and authoritybased activities in their classrooms. The SE students showed a consistently high 
participation level in the authority-based activities and mixed responses to the pair and group activities so prevelent in ESL classes in the United States which emphasize communicative competence.

As noted by the different teaching styles of the two teachers who participated in this study, teacher/student interaction patterns in ESL classes depend not only on past teacher/student experience, but to a great extent on the emphasis, goals and priorities of the current classroom teacher. In this study, one class was more reserved in its manner of participation and interaction and the other class was highly interactive with the teacher. 


\section{CHAPTER VI}

\section{CULTURAL FRAMEWORK: VIEW OF THE TEACHER}

\section{INTRODUCTION}

In chapter VI, the Soviet Evangelical students answer the third research question, "How do the Soviet Evangelicals view the teacher?" They share their perceptions of the teachers' status and prestige, their expectations of the teachers' role, and their experience with student/teacher relationships in the past. These perceptions are then related to the students' views of and experiences with their American ESL teachers.

\section{STATUS AND PRESTIGE}

In every society there are levels of authority. In the area of education, the authority invested in teachers varies greatly from one society to another. Teachers in the former Soviet Union had tremendous authority and power over their students.

\section{Authority In The Classroom}

Teachers' authority was evident first in the classroom. Teachers were always right. Students, especially young children, were not allowed to openly disagree with their teachers. However, Leonid pointed out that did not keep them from disagreeing "inside": 
Always [our teachers were right] because they have plan for every science, math, or biology. They have special plan. How they have to teach students. But inside we disagree with them. (2/14)

Teachers were treated with respect in the classrooms. Soviet students were taught to show respect by standing when the teacher entered and left the classroom, standing or raising their hand to answer questions, and addressing their teachers in a formal manner. They used such words as "respectable", "polite", "very strong", "afraid of" to describe their past teachers. Two students shook their fists and pounded on the table demonstrating the authoritative manner of their teachers. Teachers maintained rigid. strictly regimented classrooms. As recalled by a former teacher in Moscow:

Classes are organized in rows, very strict discipline. Very strict. You cannot imagine how strict it is. You cannot stand up, you cannot raise your hand, and you cannot go and sharpen your pencil, you cannot turn around. So, kids do it because, you know, I don't want to say that they are perfect kids, but they got punished for that. (12/9)

Leonid. Irena, and Svetlana confirmed this regimented atmosphere created by their teachers:

We came in at 7:00 in the morning. My teacher came in the class. We stand up. And teacher says, 'Good morning.' We sat down. (2/14)

In Russia we came to school and then the teacher ask us about homework. Everybody was afraid. (2/14)

We couldn't talk in the class. And we must listen and answer the question. About everything we couldn't talk. And with another student we couldn't talk. Only break time and lunch time. (2/9)

\section{Extended Authority}

The teachers' authority extended beyond the walls of the classroom into the students ${ }^{*}$ homes through the means of notes written to the parents. Notes were written 
most often if students failed to complete homework, misbehaved or talked in class. Every student interviewed stated that completing the huge (and often unappreciated) amount of homework they received every day was of great importance. The first task of every day was to check the homework. If a student had not completed his or her homework the teacher marked this in the student's notebook. The student's parents must then sign the notebook proving that they were aware of their child's failure to complete his or her work. Teachers also noted in this notebook when the students misbehaved and talked in class. Irena, the young mother in level 4, explained that every student in her class was responsible for informing the teacher of inappropriate behavior of other students during the school day. When asked if that caused problems among the students, she said that no one minded, it was just the way things were done.

As explained by the former teacher from the Soviet Union, these notebooks were used not just for corrections, but were also used as an assignment book and a place to praise students for good behavior:

And there is something very useful in Russia. It is called "dnevnik". It is an assignment book, a day book....It is a booklet where you write down your assignments every day and where you have your marks for each subject. Your teacher puts it in this. And there is a special place where teachers write what they want to write to parents. Like your child worked great today, or your child was very noisy today. And parents need to sign this. (12/9)

Teachers maintained discipline in the classroom, first through threat of the notes that went home to parents. But also, the students might be made to stand in a corner. write on the board, leave the class, or have a required parent/teacher meeting. Teachers were not, however. allowed to physically punish the children. 


\section{Long-Term Affects of Authority}

The authority and power of teachers was not only experienced during the school-age years, but it could play a significant role in a student's choice of occupations. For Leonid, a level 4 student, it was a teacher's intercession that made it possible for him to attend a university. Most of the students interviewed commented that at the time they were in school only members of Komsomol, Communists, could attend a university or institute. Therefore, it was surprising when Leonid said that he had attended a university and received a degree in music. He explained:

I could go to college. Because I would like to get some education. And some teacher wrote to about me that I get college. And they help me. $(2 / 14)$

Without the help of his teacher, it would have been impossible for him to have gained entrance to the university. He was the only Soviet Evangelical interviewed who had a college degree. However, even with his degree he had not been not allowed to have either a position of leadership, or any position that brought him into contact with people in a leadership capacity. Leonid had been a piano tuner at the university.

\section{Negative Use of Authority}

The most emotionally charged expression of the effects of one teacher's use of her authority came from Svetlana, a student in level 4. As an ESL student, Svetlana appeared to be the happiest of the SE women in either of the two classes. She smiled. laughed and interacted with other students more than any of the other SE women. Her description of the authority of her teachers focused primarily on her fear as a child that 
she would be removed from her home and placed in a state home. Along with that fear she also was ostracized from the other children because of lies the teacher told the class about Christian families. With tears in her eyes and her voice trembling, she recounted how her teacher told the class that Christian children were not taught the truth by their parents and were offered as sacrifices to their god.

I didn't like [my teacher] because she was Communist. She didn't like Christian children....Me and my younger brother teach with same teacher. He didn't love this teacher, too, because she didn't love us....Always, she told students that we are not right have educate from our parents. Not right teach us. And she said we should take these children from parents and will give these children to childrens' home... Yes [I was afraid]. My parents prayed too much...This woman, how can I say. Because all people aren't Christian and they didn't understand us. And when she talk bad about us, she talk children's age we are, not truth. Our parents will offer us to God...And children didn't play with us. (2/9)

Although the SE students expressed a respect for the position of their teachers. there seemed to be a contradiction between their respect for the position and for the person that filled the position. Only Communists could be teachers. And because Communist ideology was contrary to Christian ideology, it was the duty of the teachers to "persuade" their students to give up their faith and become Communists. Seven of the nine students interviewed had experienced pressure, in varying degrees, from their teachers to become Communists.

While it was the teachers' duty to persuade their students to give up their faith. the students felt it was their duty to remain strong in their faith, to "be a light" in the school. and to "forgive" those who persecuted them: 
I studied very good. I finished school only 'A' and 'B'. Because our parents teach we must be light in the school. You must be study very good. (2/9)

You must understand. They don't understand anything about that [Christianity]. You must be more higher than that and forgive them. They persuade, they must change my mind, they try to change my mind about some things. Sometimes some lessons one time per week or per month. It was usually lesson about philosophy class. Sit and reply with answer and teacher ask us trust that God is not...It is very difficult for me have another persuade. But they tried... (2/28)

In summary, teachers in the former Soviet Union had positions of power and authority. Their authority was exercised by maintaining strictly controlled classrooms; by extending their authority into their students' homes through the use of a special notebook which parents were required to sign and return; and by aiding or hindering students from receiving higher education. Teachers also used their authority to pressure the Christian children to join the Youth Clubs and become Communists.

This authority and power created respect, and in some students, fear of the teachers position. It also had the effect of lowering the teacher in the esteem of the Christian students who were negatively affected by personal discrimination. They were taught at home to forgive their teachers, to be higher than those who persecuted them and to be lights in the school.

\section{THE ROLE OF THE TEACHER}

Just as an actor is responsible to learn the lines of a role for a play, and as a mother and father have certain responsibilities deemed essential to the role of parents. so, too. do teachers have responsibilities in the role of educator. 
The SE students named three responsibilities that they viewed as important elements of the role of the teacher. They said that teachers are dispensers of knowledge, caretakers of their students, and classroom managers.

\section{Dispensers of Knowledge}

A universal responsibility of teachers is that they are "givers of knowledge". How they impart knowledge depends upon their cultural values, their individual values. and their skill as educators. In the United States, the role of the teacher as a giver of knowledge has been shifting from the teacher being the source of knowledge to the teacher being a guide leading others to the discovery of knowledge. Education has taken less of a teacher-centered approach and more of a student-centered approach. In contrast, the Soviet concept of the teacher's role continued to be that the teacher was the dispenser of knowledge, with knowledge, itself, being found in the textbooks studied by every student in the Soviet Union.

The SE students described good teachers as those who "help educate" their students. They "must like and want to give knowledge." Irena, in level 4, said that her ESL teacher "is a very serious teacher because he try to give for us knowledge and we very. very need it." As dispensers of knowledge, Soviet teachers used textbooks, lectures. and homework assignments to impart knowledge to their students:

Usually everyday we get homework [from] her. And next day she ask us about our homework. And after it she explain new materials. [We] take many, many a lot of notes. All students have their own books, notebooks, and we write down all information. In our class usually we have textbook. We read that and studied new word. Sometimes we do homework about what we know in this text. $(2 / 14)$ 
Students were not encouraged to question the truth of the texts, merely to learn it. All of the SE students said that knowledge was dispensed from teacher to student in a serious environment, as compared to the less serious environment they have seen in their childrens' American classroom. The two older Russian women explained that in Russian schools the students didn't play like they do in American schools. They think that in American schools students spend lots of time playing games. In Russian schools, they said, students studied all the time. In the classrooms the teachers talked, wrote on the board, asked questions, and taught the students. The students wrote in notebooks, they read, they had lots of homework every night in every subject. School wasn't seen by the students as a place to have fun, but to study.

Although one of the major means of dispensing knowledge was the assignment of homework, about half of the Soviet Evangelicals thought that they had received too much homework in Soviet schools. Those with children in school in the United States stated that their children have much less homework now. Several felt that the US system was much better. Their said that their children liked school more, were more relaxed and enjoyed not having such a heavy load of homework. On the other hand, other SE students stated that they did not think their children were learning as much as they did in their home countries because they did not have enough homework. An important part of the Soviet teachers' responsibility as a dispenser of knowledge was the responsibility of ensuring the success of their students. A former teacher from Moscow described the system of passing students to the next grade level: 
The whole system works to prepare you [to pass exams]...Like, I was teaching English and I knew that my kids had to take exams. So they had special books for exams and special notebooks where we wrote. If for some reason student can't do it, if it is too hard for him, they talk to parents. Teachers push him and pull him. If it is still too hard, teachers put grade ' 3 ' but keep ' 2 ' in mind...Kids were supposed to be on the same level. This was the policy of the whole government. No lower and no higher. (12/9)

When asked what happened if it appeared a student wouldn't pass the exams, she said that teachers would stay after school and would drill the child. "Because you can drill anybody like that. Probably he doesn't understand what he is doing, but he knows the answer for the test." (12/9)

This "system" was confirmed by one of Marina's sons. Although he wasn't able to say what the system was, he was aware that the teachers had "mechanisms to push the student to learn and acquire the knowledge." He repeated, while pressing his thumb to the table, that the system pushed, pushed the students if they couldn't keep up with the work.

Ivan, the level 2 student who had expressed a fairly low regard for education, had quite a different perspective on how his teachers ensured the success of their pupils:

You see, in my country if a student didn't do test good, teacher supervisor talk to teacher, 'Why these students not do good?' Teacher want students do good on test. Teacher (the student stands up and acts out the teacher writing the answers on the board) help student pass test. $(2 / 23)$ 


\section{Caretakers}

A second role of teachers as seen by the SE students was that of caretakers of their assigned students. In grades one through four the students remained with the same teacher. When the SE students felt that the teacher liked them it was a very positive situation. From grades five through ten or eleven, each student had one teacher who was his or her "care" teacher. These teachers watched out for "their" students throughout the days, weeks, and years they were in school. If a student was having difficulty in a subject or was misbehaving, the teacher of that particular subject contacted the "care" teacher to deal with the student. In some students this created a positive sense that teachers cared for their students because their teachers "connected" with them:

She can to find contact between student and between her. She build, or make good atmosphere in the class. (2/14)

We have one teacher, every class have one teacher who have care for the students. One teacher. Probably it's care teacher who good for me. Sometimes smile, sometime, oh, she, she was very friendly. She like go to park, every class to park. Or to the movie, or to the forest. $(3 / 7)$

This sense that teachers should care for their students has transferred with the SE students into the ESL classes. When asked what made one ESL teacher better than another, Ivan and Andrei, both in level 2, said that the teachers who showed that they cared for the students personally were the better ones. Ivan said that because his first teacher had understood him, he felt that he could bring to her problems with bills, with words. with English and she understood him and could help him. 


\section{Classroom Manager}

A third responsibility in the role of the Soviet teacher, was to keep order in the class. As already noted, Soviet classrooms were strictly controlled. Apparently, however, this was not always the case. While a quiet classroom was the goal and the norm, a few of the SE students described classes that didn't meet that goal. When classes were noisy, it was generally considered to be the students' response to a teacher who was not "very good." Ivan described a class that was definitely not quiet:

Much talk, much talk. Students yelling, yelling, teacher yelling. (He gestured with his arms to show teacher waving arms and then pounded on the table to indicate teacher's actions) Sometimes teacher yell, yell, and then hit. (2/23)

Svetlana shared that when students reached about thirteen years of age they sometimes got into trouble for being too noisy in class. She said that on several occasions her entire class, which was "very friendly", was told by the teacher to "get out" of the classroom---he sent them home. She added, "But usually after this, the teachers called our parents for a meeting." (2/9)

Tasha attributed the cause of noisy classes to problems shared by both the teacher and the students. She said that some teachers were boring, and that perhaps some students didn't like a particular subject. Whatever the reason, she was very adament about the superiority of quiet classes over noisy classes. Quiet classes were good for thinking and for studying. Noisy classes were very bad for students who wanted to learn. It was, she felt, the teacher's responsibility to maintain a quiet class. When asked if she preferred her ESL classes to be quiet, Tasha said that the teacher 
"must make order...Yes, yes, absolutely [I prefer a quiet class]. Only quiet. It's very easy for studying."

Not all of the SE students like such an ordered class. Some enjoy being able to talk more freely and openly. Andrei, in level 2 , stated that he preferred to be able to talk to his neighbor and to interact more freely with the teacher:

Big difference this. In Ukraine is sit only. I have questions, pick up my hand. Every student only quiet is...I think English class is more better for me. It big free. Sometimes in Ukraine teacher angry. Sometimes no happy. (3/7)

With some students liking a quiet and structured class and others preferring a more open and interactive class, ESL teachers find themselves in a dilemna. However, the consensus among the SE students was that the teacher was the authority in the classroom, and it was the teacher's responsibility to manage the class. Being accustomed to authoritative teachers, the SE students didn't resent their ESL teachers when they were reprimanded for talking out of turn. The level 2 ESL teacher noted that on the days when the class was too talkative they responded best when she became "a little angry." One day, when the level 2 class had a subsitute teacher, the teacher warned Andrei to quit talking to his neighbor. After two warnings she told him to move to a different table. After class when asked what he thought of this teacher, he enthusiastically said that she was "a very good teacher. I like very much this teacher."

Summarizing the role of teachers as perceived by SE student, teachers are givers of knowledge, caretakers of their students, and good classroom managers. Those students who had been fortunate enough to be in classes with teachers who 
fulfilled these roles, usually experienced positive student/teacher relationships. But when teachers failed in one or more of these responsibilities, the students lost respect for the teacher and the student/teacher relationships became strained.

\section{EXPERIENCE WITH STUDENT-TEACHER RELATIONSHIPS}

The status and authority of teachers, as well as how well they fulfill the role of the teacher, determine the kind of relationships that exist between students and teachers. If students are afraid of their teachers and see them as "not too close," the relationships will be embryonic or destructive; if the students feel that their teachers "make connection" with them and care for them, the relationships will be productive and positive in the students' lives. The SE students expressed having experienced both positive and negative teacher/student relationships.

\section{Positive Teacher/Student Relationships}

Of the nine SE students interviewed, seven spoke specifically of their past relationships with teachers. Three of the seven remembered having a positive relationship with a favorite teacher. Traits that made one a favorite teacher were: the teacher was a "good teacher" and a "good friend"; "helped children with problems"; "made connections with her students"; "smiled" and "was friendly" and took her students "to the park and to movies." These three students felt that they had many good teachers throughout their school years. They said that they definitely enjoyed going to school: 
I [had] many favorite teachers. One favorite teacher was Germany language and she was very good woman. And I liked her because she was very good teacher. Very good friend...She understand child problem. $(2 / 8)$

She build, or make good atmosphere in the class. (2/14)

I don't have teacher didn't like. (3/7)

Two of these students, Igal and Leonid, enjoyed school in spite of the fact that as Communists, many of their teachers spoke negatively about and sometimes were unkind to Christian students.

When I going to school always teacher talk about this problem. Christian people not good...Teachers made bad things and the teachers was always pressures and [jokes about] devout Christians. (2/8)

We feel sometimes about reason we are Christian many teachers don't like people look like us. Different. They sometimes was not very kinds....In our school we didn't met teachers, Christian. They weren't Christian. Because if they were Christians they can not get work look like teacher.(2/14)

The third student, Andrei, liked all of his teachers and said that his teachers treated all students alike.

\section{Negative Student/Teacher Relationships Based on Religious Persecution}

Three of the seven SE students who spoke of their past relationships with teachers had very strong negative feelings toward their Soviet teachers. For two of the students, these feelings were related to religious discrimination and persecution by their Communist teachers. Svetlana plainly stated that she was afraid of her teacher who was a Communist and didn't like Christians. Her teacher threatened to have her removed from her family to live in a state run group home. Although this didn't 
happen, she knew other children who were taken from their families. The reality of threats being carried out was very real to Svetlana because her father had been imprisoned for five years for having a church meeting in his home.

Irena stated very explicitly that she didn't like her Soviet teachers. She felt that they were all against her:

When I was study in school it was very hard time because I'm Christian religion. And in my country it was very difficult for these kind of people. And each teacher in my school was against me. Like, if I know some word, if I do some work like good and excellent and teacher look and said no, it's like I did something for excellent but teacher put mark something bad...But it was at first level. Like first, second, third, fourth. But later change. Time began to change some. Better...But, each teacher was not good for us. (2/14)

The third student who had negative past experiences with his teachers was Ivan. He simply did not like many of his teachers. He, too, felt discriminated against because of his religion, but he did not elaborate on it:

No! Don't like [teachers]. Some teachers, yes, others, no like. No [I don't like school]...I very quiet about what my parents believe.

Necessary to be very quiet. Because if teacher knew that my parents believe, it very bad for me. Must be Komsomol, must be Communist. If teacher knew Christian, say, these parents teach bad to children. $(2 / 23)$

Tasha, the seventh of the SE students who spoke of their past teacher/student relationships, smiled and said she could not really remember if she had any favorite teachers and was noncommittal regarding whether she had liked school. But she did remember having teachers who pressured Christian children to deny their faith. Her worst experiences in school were during her first thirteen years when she lived in Russia. After her uncle, who was a pastor, was arrested, the family moved to 
Kazakhstan. They found it safer there for Christians and it was better for her in school.

The SE students had a wide range of past student-teacher relationships. About half of the students had experienced some very positive relationships while the other half had endured some very negative relationships. Though it is not necessary or even possible for ESL teachers to have meaningful relationships with all of their students, it is important for them to be cognizant of the fact that some of their Soviet Evangelical students may have a background of negative memories of past relationships with their teachers. And, these memories may impact the students' ability to relate to their ESL teachers.

\section{SUMMARY}

This chapter looked at the Soviet Evangelical students' view of the teacher. In the former Soviet Union teachers held a high degree of power in the classroom, beyond the classroom into the students' homes, and beyond the students' homes into their opportunity for higher education and careers. The SE students saw the role of the teacher carried out in three ways: imparting knowledge, caring for students, and managing classrooms.

When the authority invested in the teacher combined positively with the role of the teacher, positive student/teacher relationships resulted. When teachers used their authority negatively to demean or threaten the students, the resulting relationships were ones of fear and disrespect. 


\section{CHAPTER VII}

\section{CULTURAL FRAMEWORK: CORE VALUES}

\section{INTRODUCTION}

In Chapter VII, research question four, "What are the cultural values of Soviet Evangelicals that relate to teaching methods and classroom practice," is addressed. This chapter looks at the core value of individualism verses group orientation, the core value of time, and the core value of education as they relate to the SE students' view of and participation in ESL classes.

It is the core values of a society that most often cause conflict between cultures. While differences in dress, preferences in food, preferred leadership styles do cause conflict, it is the core values, which are usually intangible and often not recognized, that are the basis from which the more surface differences emerge. Without an understanding of these issues, ESL teachers and Soviet Evangelical students are cultures in conflict.

\section{INDIVIDUAL OR GROUP ORIENTATION}

Most Americans would agree that they place great value on the individual, individual rights, and individual achievement. Individualism is, in fact, a basic 
foundation of American life. It permeates every arena of our society---from the classroom to the church to the courts of law.

In contrast, Russians and many of the cultures that made up the former Soviet Union place great value on being part of a group. The group from which Soviet Evangelicals have gained their identity, sense of stability and security is the Church. Ironically, Soviet Evangelicals have endured a lifetime of persecution, economically, spiritually, and educationally, because of their adherence to this group. Having arrived in the United States within the last one to three years, their main support system has remained their church association. While the United States government has supplied them with financial support for a limited period of time, the church has continued to meet their emotional needs as well as many of their physical needs.

This sense of belonging to a group forms a cohesiveness among the SE students that manifested itself in three observed behaviors or attitudes in the two ESL class rooms: camaraderie of believers, exclusion of "out-siders", and admonision and . correction of others.

The camaraderie of the students in the two ESL classes was observed in their shared laughter and in their fellowship together during breaks. In both classes, there were members of Baptist churches, Pentecostal churches, and Seventh Day Adventist churches. Many of the students were members of the same church and therefore friends outside of class. Several students lived in the same apartment complex, and others lived in the same neighborhood. Many shared rides to and from school. During breaks the SE students gathered in groups in the halls or in the mall and talked 
together. On one occasion a large group of students gathered around a table at break and engaged in a lively discussion of the Bible.

Teachers have complained that a second manifestation of the cohesive nature of Soviet Evangelical students is their exclusiveness of anyone who is not "one of them". On five occasions I was invited by non-Soviet students to join in a conversation either alone or with a group. Only after I was in the process of arranging interviews with specific Soviet Evangelical students did they initiate conversations with me. Several of the women became very gracious and friendly and the men would greet me in the halls.

Many ESL teachers believe that what they view as exclusiveness, but what the SE students consider cohesiveness, limits the Soviet Evangelicals' participation with non-Soviet students and subsequently hinders their English acquisition. This apparent teacher/student conflict of values can lead to a negative image of Soviet Evangelical students in the eyes of some of their ESL teachers. Carol stated on several occasions that the SE students were exclusive and egocentric:

Can you believe how egocentric they are? In their country they had no concept of anyone or any place outside of their own community and the United States. I had one man who was so prejudicial that he walked out of class rather than talk with a Vietnamese. (fieldnotes, 2/2)

The SE students' experience was very different from that of the average American student. First, they were accustomed to attending mono-cultural classes. A few of the students interviewed said that in their school there were only Russians. Others had only Georgians in their school. The schools were segregated by nationality. 
Second, as Svetlana said, the SE students were cautioned by their parents to associate only with other Christians for safety reasons:

Most of us did not do it [take part in after school activities] because they, Russian parent educate us, Christian people, that we...don't want be a long time with other children because, not so good this. (2/9)

Adherence to their religious faith made them susceptible to harrassment from neighbors, police, and "friends". Ivan gave an example of their need for caution and and for confining their association to other believers:

Very hard for Christian...after 1965, if police catch Christians together, they ticket. You must pay....Example, marriage day, what you call it? Wedding day, you to friend's house for wedding. Many people come for this wedding day. But neighbors looking, looking, calling to police.

Police will come. They will ask who are you, who are you. They write names of people there. They ask who is this house? These people they will write ticket. Police phone school your children, talk to supervisor...Then police call job. Tell you boss. He will get everybody together. He say them, this man does bad. He teach his children bad. This man will get less money. (2/23)

The suspicion and caution which were necessary to survival have carried over to their experiences in the United States. Tasha expressed that she "[has] nothing [American friends]. I try to get along with neighbors. But I think maybe I can't to trust them" $(2 / 28)$.

Svetlana and Tasha, and other SE students agreed, that not wanting to pair up with Vietnamese was not because of racial prejudice, but it came out of frustration caused by an inability to understand the Vietnamese students, thus making it a poor use of valuable class time:

Yes, it's okay [pairing up with non-Russian speakers]. But Vietnamese student hard to understand. But Japanese good and Mexican. But Vietnamese hard. (2/9) 
Also I have to tell you about when we came to America and get in ESL classes first level, also second level, it was very difficult... We did not have too much time to learn. Two hours a day. And we must to get more information, more, more, more and more English and we don't understand. Because people some making group of people. And teacher said talking between our own and Japanese. And sometimes, I absolutely don't understand his or her and he or she don't understand me. It's very difficult to make conversation when are to sit only and listen to them talking but not, don't study English that way. I miss lot of lessons I think so. I don't understand, I just don't. So. I understand some Spanish peoples, and some European is okay. $(2 / 28)$

Observation of both classes confirmed this lack of initiative on the part of the Soviet Evangelical students to engage in informal conversations with non-SE students. However, when they were specifically paired up with a non-Russian speaking student most of the SE students would participate in the activity. Not always were these pair activities rewarding to the participants, as noted during a pair activity in level 2 . At one table, two SE men were working together. They were speaking in English and seemed to be making their way through the questions. At the same table another pair, a SE man and an older Chinese man were working together. The SE student tried to explain the instructions but the Chinese student didn't understand. Though they kept trying to work through the worksheet, they didn't get very far. At the end of the activity the teacher told the class to keep the papers and said that they would continue the next day with the same partner. Although the SE student didn't say anything, he looked frustrated.

According to the literature, this sense of "group belonging" that is typical of Soviet people in general, contributes to their freedom to admonish one another and be involved in one another's lives (Richmond, 1992). This third manifestation of 
cohesiveness showed up repeatedly in the Level 2 class. Students were quick to correct one another's answers, grammar, and pronunciation during whole class interaction activities. They were not hesitant to ask Carol personal questions about her life, such as what she did before she taught ESL and where she has travelled. On one occasion they asked her what her favorite country was and then told her she "should go to Russia". At times their rather blunt questions and their quickness to correct others appeared rude by American standards.

An example of their involvement in each other's lives was observed in the manner in which the level 2 students took their end-of-the-quarter test. Early in the test the teacher repeatedly told the students to do the test alone, "We do lots of group work," she said, "but this is to be done alone." There was a lot of talking in Russian among classmates. They repeated words, they gave each other answers, they asked each other questions. Some whispered, some talked in regular voices, some talked from one table to another. Though the teacher repeatedly told the students to work on the test alone, they continued to help one another thoughout most of the test.

\section{USE OF TIME}

If people spend time on that which is of greatest value to them, then the Soviet Evangelical students most value their families and their church. Because most of them had large families, the nine SE students interviewed said that they spent a lot of their time outside of ESL classes taking children to doctor and dental appointments, helping children with homework, and taking care of personal family needs. Those with jobs 
spent their afternoons or evenings at work. Church related activities also took up much of their time. Soviet Evangelicals, they said, spend an average of three evenings a week at church, plus Sunday (or Saturday) morning.

Of particular importance to ESL teachers is the fact that a significant number of students interviewed did not feel that they had time to do homework nor did they have opportunities to meet Americans; thus they did not speak English outside of the ESL classroom. Ivan's comments reflect a conflict of values shared by many of the SE students interviewed.:

I would like speak English more. Would like have American friend. But, not...On Saturday I go to church 10:00 a.m. to 6:30 p.m...Sunday I my family. I like fish...Tuesday 6:30 to 8:30 meet church. Pray, sing songs, study Bible. Thursday, meet pray, sing, study Bible. (2/23) Ivan emphasized that all work should be done in class. He said that if teachers think ESL students will do homework, they "fool themselves". He would like to have time to do homework because he said that he knew it would help him learn English better. He thought that if he were single or had only one or two children, like the Vietnamese, he would have time to study. But he had seven children and didn't have time. As a pastor of his church he said that he had talked with others and knew that they, too, were busy:

They go out and look for job, or have job. It important teachers to know that English must be learned in class. (2/23)

Leonid, a level 4 student, said that he used to do homework, but not anymore:

Right now I didn't work in my house. I didn't do homework. But in first six months I worked very hard. All my free time I learn English, English, English. Because now for me easy understand many things. I don't study hard now. If I study hard now, I know my English was better. (2/14) 
Lack of time sometimes combined with other issues in the SE students' lives to make completion of homework a challenge. Tasha, who was divorced and raising her teenage sons alone in a foreign culture, said that much of her time was spent thinking about her personal and family problems and concerns. Her mental and emotional health seemed to consume the majority of her time:

I am sorry, not too much [time to do homework]. I have, maybe, yes, I have [time]. But I don't use it so much. Because really I can't explain my life. I need some changing. It difficult to explain. Single people usually have a lot of lot of problems. It's a new country, it's a new culture, it's new, you're alone...Then at home thinking. Probably they have time. But they don't thinking so much about English. But their problems. They spend a lot of time not doing their homework. [And have] problem with teenager also. $(2 / 28)$

Not all of the SE students found it difficult to schedule in study time. Andrei, the young father of three, who was so enthusiatic in the level 2 class, wanted to study and learn English as much as possible:

I am teach [study] in homework right now. Every day. Some days I am learning in home English, English. Sometimes I translate English.

Sometimes...I am study in class I am going to repeat, repeat this...I have free time, I learn English. (3/7)

At the time of the interview, he was just finishing a Mark Twain novel that an American friend had given him.

Marina, who was over seventy years old, was another example of a student who enjoyed studying at home. During a level 2 group activity, as the students were walking around asking each other questions, it was noted that her worksheet was almost all filled in with names. She commented that she had done her worksheet at home the night before. She turned over her paper to show where she had written out 
all the questions and variations of questions the teacher had given the day before. She said that she liked to do it at home because she could take time to think. The class went so fast that she could not think fast enough..

While ESL teachers would like to think that their students value learning English enough to apply themselves to the task of studying and speaking it outside of class, they may need to recognize the existence of a conflict of priorities. Large families, busy lifestyles, cultural adjustments, becoming "adequate" users of English combined with the limitations of "time" may well conflict with teachers' recognition that students have only a limited amount of time to take advantage of government funded ESL classes.

\section{THE VALUE OF EDUCATION}

The United States and the former Soviet Union probably would find that they both place a high value on education: both make education mandatory and free for all children from first grade to tenth or twelfth grade; both have high quality training programs for teachers; and both provide educational curriculums that attempt to foster well-rounded, well educated citizens.

Of the nine Soviet Evangelical students interviewed, all but one expressed an appreciation for education. These men and women enjoyed learning, most making high marks in school. The conflicts in values and beliefs between Christianity and Communism, however, made it impossible for them to accept certain portions of the 
curriculum, such as philosophy classes, some portions of science classes, political science classes, and the Communist youth organizations.

Svetlana said that because only members of the Communist Party could attend the state funded universities, many of the Christian high school students in her school gave up their efforts at studies and dropped out of school to become workers:

You understand, first level, fourth, fifth, sixth levels most of Christian children very good study, but after this they understand that Christian people couldn't go to institute, college, because we're not Komsomol...So, in later grades like eighth, ninth, tenth, eleventh many Christian students didn't go to school. Most of Christian go to school until eighth grade then they go to work. (2/9)

In the past eight to ten years, there were some cities in the former Soviet Union where Christians were allowed to enroll in institutes and universities. However, upon graduation, many found their degrees basically useless in obtaining financially secure occupations. The interview with Olga and Marina, the two sisters in level 2, turned into a family interview in Olga's home, with their families providing insights into the educational experiences of two generations of Christians in the Soviet Union. Olga, Marina and their husbands had recieved no more than high school educations. Both of the husbands were "laborers" in Russia. Of the three adult sons, all had attended the University in Rostov, Russia. At one point in the evening the father shook his head sadly and said, "All my children have this education, but I have nothing. I have not the opportunity for this education." Their thirty-year-old son, who had obtained a degree in engineering, said that he was paid thirty dollars a month as an engineer. That wasn't enough to live on, so he became a worker in order to provide for his 
family. One went to the university, he said, for personal pleasure and enjoyment of learning, not for career advancement.

This assessment of the value of education for the Russian people as a whole was confirmed by the comments of a former teacher from Moscow:

If education is not important in your family, it's easier to live in Russia if you don't have high education. Because people, like taxi drivers or people that work in stores...make more money than teachers and doctors and engineers. Engineers were the lowest paid profession and there were even lots of jokes about them. Here [in the United States] people go [to the university] because they want more money. In Russia it was visa versa. If you want a lot of money you don't need to go [to the university]. If you are average engineer your salary is much less than if you are average taxi driver. This is the Soviet reality. (12/9)

The one student interviewed who had a low opinion of education in his country was Ivan, who had been an interior designer in Russia. He indicated that a piece of paper (a degree) was worthless when it came to job interviews. Employers, he said, looked for experience, not education:

I no go to college. No good teachers. I work, study, work. Better. Because, when finish college have license. But not good. Better work, learn, work, learn. College no good. When go for job, ask you how many years you work. License no good. $(2 / 23)$

Of particular interest to ESL teachers is the value Soviet students placed on learning a second language. All of the students learned Russian and if they were Ukrainian knew Ukrainian. But learning German, French, or English was also required in the state mandated curriculum. Students began studying a foreign language in the fourth level, meeting for forty-five minutes three or four times a week throughout high school. Without exception every SE student interviewed felt that their language study had been worthless. When asked why they hadn't enjoyed learning a foreign language 
they replied that they never dreamed they would leave their home country, certainly they would never live in America. They saw no need to learn the language of a country they would never see. "Students," said Leonid, "don't want to learn it because they say I know I have to live all my live in here. Why I need to learn other language?" (2/14). Svetlana agreed, "I didn’t study English in school because I thought I don't go to America. I didn't know that I come here." (2/9)

In contrast, every student interviewed sensed an immediate need to learn English once they came to the United States. English proficiency, they said, was needed to obtain jobs. Several of the level 4 students indicated that they planned to complete level 6 and then enroll in Compton Community College. They were not sure what kind of skills training they would pursue, but they were aware of a need for specific training, with English acquisition being the first priority.

As a confirmation of their appreciation of the value of education, many of the students hoped that their children would attend college. Leonid, the one SE student who had attended a university in his country, had a son who was enrolled in a private college in the Pacific Northwest. He hoped his other children would be able to attend college as well. Igal also wanted to see his children attend college after high school. Tasha's son was enrolled in Compton Community College's dental assistant program. And Svetlana, who had teenage sons, simply hoped that she could manage to get them through the high school years.

The appreciation that these SE students expressed for the need of an education is a contradiction to the perception held by many ESL educators in both public high 
schools and adult education classes. The Soviet Evangelicals have been described as having no ambitions for a higher education and as being satisfied with common labor jobs, such as construction and driving trucks. The fact that many Soviet Evangelicals have a goal to be "truck drivers" and "factory workers" may not indicate a disrespect of or lack of motivation for higher education. Rather, it may be an extension of past experience. In the former Soviet Union being a truck driver provided a better life for one's family than being a college educated engineer.

Do the Soviet Evangelicals have a high value of education? From the interviews, it seemed that the SE students in this study had a pragmatic view of value of education. They enjoyed learning in their elementary and high school years. But the fact that higher education was withheld from most Christians, combined with the economic reality that higher education rarely enhanced their earning power, diminished its value. The value of learning for the sake of learning was not expressed by the SE students in this study. This would be an appropriate study to be undertaken by a researcher who could interview the students in their native language.

\section{SUMMARY}

In this chapter three core values of Soviet Evangelicals that impact their participation in ESL classes were explored. The value of the group and the value of time were found to conflict in some ways with values/priorities held by American educators. The third value, the value of education, was highly regarded by most of the 
Soviet Evangelicals, but because higher education was withheld from them, and it rarely provided better jobs, the importance of education diminished.

Being aware of these potential areas of conflict can help ESL teachers structure group activities, develop practical homework assignments, and focus on educational opportunities available to the SE students and their families. 


\section{CHAPTER VIII}

\section{SUMMARY AND IMPLICATIONS FOR TEACHING}

In this final chapter, the research is summarized and discussed. Goals and methods of the investigation are reviewed; the cultural framework is presented; and the implications for teaching are discussed.

\section{SUMMARY OF THE STUDY}

The purpose of this study was to discover and describe the cultural and educational values of Soviet Evangelical students that affect learning in the ESL classroom. The goal of the study was to provide a framework from these values that could be used by ESL educators for cross-cultural analysis of teaching methods and classroom activities.

The need for a study of this nature comes from several factors. Since 1988 , with the dissolution of the former Soviet Union, thousands of Evangelical Christians have left their former Soviet homelands, arriving in the United States as religious refugees. With the provision of language education promised to refugees by the United States government, many ESL classes have a high student enrollment of Soviet Evangelicals.

The influx of this student population has presented educational and social challenges to ESL educators and administrators. The Soviet culture, particularly the 
Soviet Evangelical culture, is unknown to most Americans. A review of the literature and related research confirmed a dearth of information on Soviet Evangelicals.

Therefore, a qualitative study was designed to investigate limited aspects of the Soviet Evangelical culture. Four broad questions suggested by Furey (1986) were used as the guiding questions. A fifth question relating to ESL teachers' view of Soviet Evangelicals was also asked. Each research question was followed by a number of secondary points that further explored each area of study.

Research question one looked at the Soviet Evangelicals's modes of learning. Information was gathered on how they like to learn in terms of preferred teaching methods and activities.

Research question two asked about the Soviet Evangelicals' classroom experiences in teacher/student interaction patterns. The study sought to understand the kinds of teaching methods and activities with which SE students were most familiar; to gain insight into their experiences in student participation in Soviet classroom; and to note their interaction patterns in ESL classes.

Research question three focused on how the Soviet Evangelicals view the teacher. Attention was given to their perceptions of the status and prestige of the teacher: to their expectations of the teacher's role; to their past experiences with teacher'student relationships.

Research question four sought to determine the cultural values of Soviet Evangelicals that relate to teaching methods and classroom practice. Specific areas addressed were the Soviet Evangelicals' orientation toward the group rather than 
toward individualism; their attitude toward the use of time; and their value of education.

Research question five asked how their ESL teachers view Soviet Evangelicals. Because there were only two ESL teachers involved with the study, and because their views often differed, it was not realistic to draw conclusions about ESL teachers' views of SE students. Therefore, the views of the ESL teachers in the study have been applied to and interwoven within the first four questions rather than addressed separately.

The research method used in this study was a qualitative case study. A qualitative rather than quantitative study was chosen as the means of investigation because the study was exploratory in nature and because it permitted the use of multiple research techniques. Qualitative studies are often used when "researchers are interested in insight, discovery, and interpretation rather than hypothesis testing" (Merriam, 1988, p.10).

The population of the study was restricted to adult Evangelical Christians from former Soviet countries who were enrolled in adult ESL classes in the Pacific Northwest. Two classes, a level 2 ESL class and a level 4 ESL class in a community college were selected as the case sites of the study. The selection of the two classes was based on the willingness of the ESL teachers to participate in the study, the capability of the students in the classes to participate in simplified English language dialogue with the researcher, and a Soviet Evangelical student population diverse in age and gender. 
Study participants included all of the SE students in both classes during the classroom observations. Possible study participants in the formal interviews, in level 2, were selected from the population by their classroom teacher. Selection was based on her assessment of their willingness to participate and their language ability. Of the teacher recommended students, two men and two women were selected based upon their availability as well as their willingness to participate. The two women's lack of language proficiency was overcome by using one of the women's sons as an interpreter. Three men and two women in level 4 were selected as participants by the researcher based upon their willingness to participate and their accessibility.

Data were gathered through in-depth interviews, a survey based on preferred modes of learning, and classroom observations. The interviews followed an interview guide that was based on a combination of open-ended and closed questions. The primary method of classroom observations was participant observation with the researcher achieving a moderate participant level. A secondary method of classroom observation was the use of an observation analysis system. This system was used on a limited basis in each classroom. The language learning preference survey was administered to SE students in both ESL classes in order to determine if there were certain preferred modes of learning and class activities common to the SE students in the two classes in the study.

Analysis began after the first classroom observation and first formal interview and continued through the final synthesis and generation of a cross-cultural framework. Themes and categories arose from recurring patterns within the data. Each ESL class 
was analyzed separately and then both classes were brought together in synthesis of common themes, patterns and categories. The interviews were treated in the same manner, first analyzing each case separately and then bringing all together.

\section{DISCUSSION OF FINDINGS}

The information gathered from the four research questions addressed in this study forms a cultural framework of the values and educational experiences of Soviet Evangelical students. The four dimensions of the framework are modes of learning, teacher/student interaction patterns, the view of the teacher, and cultural values.

\section{Modes of Learning}

Table III shows the past and present teaching approaches experienced by SE students, along with their responses to these differnt approaches. The literature indicates that teaching methods in the former Soviet Union stressed authority-based teaching and learning. According to the SE students' descriptions of their classes, they are accustomed to hearing teacher-delivered lectures, taking extensive notes, memorizing facts and completing hours of homework on a daily basis.

Based on the results of the survey of how they like to learn English, based on the student interviews and based on classroom observations, SE students show a strong preference for "authoritative" teaching methods and activities. They like the teacher to explain everything; they like to write everything in their notebooks; they like to do dictation: and they like to study grammar. The activities that have consistently high SE 
TABLE III

CULTURAL FRAMEWORK: MODES OF LEARNING

\begin{tabular}{|c|c|c|}
\hline PAST TEACHING APPROACH & $\begin{array}{l}\text { PRESENT TEACHING } \\
\text { APPROACHES }\end{array}$ & STUDENT RESPONSES \\
\hline $\begin{array}{l}\text { A. Authoritative Grammar Translation } \\
\text { Approach: } \\
\text { - Learn rules of language } \\
\text { - Memorize facts and vocabulary } \\
\text { - Textbook-based } \\
\text { - No communicative use of language }\end{array}$ & $\begin{array}{l}\text { B. Class A:Communicative Approach } \\
\text { - Communication in target language is } \\
\text { goal. } \\
\text { - Students work regularly in groups } \\
\text { and pairs. } \\
\text { - Activities: role play, drama, human } \\
\text { bingo } \\
\text { - Not textbook based. } \\
\text { C. Class B: Grammar-Based Approach } \\
\text { - Textbook based. } \\
\text { - Learn rules of language. } \\
\text { - Students work in pairs and small } \\
\text { groups. }\end{array}$ & $\begin{array}{l}\text { B. Class A: Communicative Approach } \\
\text { - Most not comfortable with } \\
\text { approach. } \\
\text { - Varying levels of participation in } \\
\text { group and pair work. } \\
\text { - High participation in dictation and } \\
\text { grammar assignments. } \\
\text { - Preference for textbook based. } \\
\text { C. Class B: Grammar-Based Approach } \\
\text { - Most are comfortable with } \\
\text { approach. } \\
\text { - Prefer more "life speech" } \\
\text { - Low participation in optional pair- } \\
\text { work. } \\
\text { - High participation in prescribed } \\
\text { pair-work. }\end{array}$ \\
\hline
\end{tabular}


student participation levels are authority-based, such as dictation and individual grammar assignments. The activities that have mixed responses among the SE students are communicative activities, such as pair and group work. Activities that require student initiative have especially low responses.

The SE students also said that they do like some of the communicative activities common to ESL classrooms striving to produce communicative competence. Students in level 4 said that they would like to have more "life speech" in the classroom because they do not have many opportunities to speak English outside of the class room. Students in both classes said that they know they need to speak English in class, but several said they were shy about speaking because they "are not good".

\section{Teacher/Student Interaction Patterns}

Table IV shows the different kinds of teacher/student interaction patterns experienced by the SE students in their past Soviet classes and in their current ESL classes. It also shows how the SE students respond to the different kinds of interaction patterns in their ESL classes. Teacher-student interactions in Soviet schools were strictly regulated and teacher-directed. Teachers lectured and students took notes; teachers posed questions and students answered. There was dialogue between teachers and students, but there was not dialogue or interaction between students and other students. SE students were not accustomed to being given choices, having class discussions, or taking part in group and pair activities.

Class observations revealed that when an ESL class is primarily teacher-led, the SE students follow the interaction patterns with which they are accustomed. They 
TABLE IV

CULTURAL FRAMEWORK: TEACHER-STUDENT INTERACTION PATTERNS

\begin{tabular}{|c|c|c|}
\hline PAST INTERACTION PATTERNS & $\begin{array}{c}\text { PRESENT INTERACTION } \\
\text { PATTERNS }\end{array}$ & STUDENT RESPONSES \\
\hline $\begin{array}{l}\text { A. Teacher/student: } \\
\text { - Questions to specific students } \\
\text { - One right answer }\end{array}$ & $\begin{array}{l}\text { A. Teacher/Student } \\
\text { - Class A: directed to whole class } \\
\text { Class B: combination, individual and } \\
\text { whole class }\end{array}$ & $\begin{array}{l}\text { A. Teacher/Student } \\
\text { - Class A: much speaking out; a few } \\
\text { dominate interaction } \\
\text { - Class B: needs ecouragement to speak }\end{array}$ \\
\hline $\begin{array}{l}\text { B. Teacher/class: } \\
\text { - Teacher lectures } \\
\text { - Students takes notes } \\
\text { - No class discussion }\end{array}$ & $\begin{array}{l}\text { B. Teacher/Class } \\
\text { - Class A: interactive teaching times } \\
\text { - Class B: lectures with questions }\end{array}$ & $\begin{array}{l}\text { B. Teacher/Class } \\
\text { - Class A: students ask many questions } \\
\text { - Class B: students take notes }\end{array}$ \\
\hline $\begin{array}{l}\text { C. Student/teacher: } \\
\text { - Asks questions } \\
\text { - Answers questions }\end{array}$ & $\begin{array}{l}\text { C. Student/Teacher } \\
\text { - Class A: encouraged to ask task } \\
\text { oriented and personal questions } \\
\text { - Class } \mathrm{B} \text { : encouraged to ask task } \\
\text { oriented questions }\end{array}$ & $\begin{array}{l}\text { C. Student/Teacher } \\
\text { - Class A: many questions to teacher; } \\
\text { sometimes seem blunt and aggressive } \\
\text { - Class B: very little student initiated } \\
\text { questions to teacher }\end{array}$ \\
\hline $\begin{array}{l}\text { 1). Student/student: } \\
\text { - None } \\
\text { - No pair or group work }\end{array}$ & $\begin{array}{l}\text { D. Student/Student } \\
\text { - Class A: pair and group work } \\
\text { - Class B: pair and group work }\end{array}$ & $\begin{array}{l}\text { D. Student/Student } \\
\text { - Class A: varying levels of } \\
\text { participation; high use of } \mathrm{L} 1 \\
\text { - Class B: varying levels of } \\
\text { participation; low use of } \mathrm{L} 1\end{array}$ \\
\hline
\end{tabular}


respond to the teacher's questions when the questions are directed to individuals. When the questions are directed to the whole class, they respond less frequently, or not at all. They do not initiate questions to the teacher, but ask questions when s/he walks around the class during individual or group work.

In a class that strongly emphasizes communicative teaching methods, the SE students' interaction patterns change dramatically from their accustomed patterns. Open class discussions, encouragement by the teacher to mix with other classmates in interactive activities, and class directed questions seem to result in student dominated interaction. The students interrupt, ask many questions and speak to one another during teacher directed activities.

\section{The View of the Teacher}

Table V compares the differences in the perceived status and roles of Soviet and American ESL teachers, along with student responses to their ESL teachers in this area. In the interviews, the SE students described teachers in the Soviet Union as being very powerful and having much authority. Teachers were treated with respect in the classroom. They were formally addressed and they were never contradicted. They were in many ways a controlling force in the Soviet school child's life. The SE students used terms such as "respectable", "very strong", and "afraid of", to describe their teachers.

The Soviet teacher's role included dispensing knowledge, caring for their students, and managing their classrooms. Teachers in the Soviet system followed a rigid state mandated curriculum. And while it was their responsibility to "give 
TABLE V

CULTURAL FRAMEWORK: VIEW OF TEACHER

\begin{tabular}{|c|c|c|}
\hline PAST EXPERIENCES & PRESENT EXPERIENCES & STUDENT RESPONSES \\
\hline $\begin{array}{l}\text { A. Status: } \\
\text { - High in power and authority } \\
\text { - Treated with respect by students } \\
\text { - Feared by student }\end{array}$ & $\begin{array}{l}\text { A. Status } \\
\text { - Power limited to classroom } \\
\text { - Casual relationship with students; } \\
\text { first name used in classroom }\end{array}$ & $\begin{array}{l}\text { A. Status } \\
\text { - Most not initially comfortable using } \\
\text { first name } \\
\text { - Not feared by student }\end{array}$ \\
\hline $\begin{array}{l}\text { B. Roles: } \\
\text { 1) Dispenser of knowledge } \\
\text { - lectured, used text } \\
\text { - always right }\end{array}$ & $\begin{array}{l}\text { B. Roles } \\
\text { 1) Guide to knowledge } \\
\text { - students make own discoveries } \\
\text { - not always right }\end{array}$ & $\begin{array}{l}\text { B. Roles } \\
\text { 1) Dispenser/Guide } \\
\text { - Want to use textbooks } \\
\text { - Want teacher to tell them facts } \\
\text { - Want to take notes }\end{array}$ \\
\hline $\begin{array}{l}\text { 2) Caretaker } \\
\text { - reported to family } \\
\text { - responsible for academic success } \\
\text { of students }\end{array}$ & $\begin{array}{l}\text { 2) Advisor } \\
\text { - makes information known } \\
\text { - students responsible for own } \\
\text { learning }\end{array}$ & $\begin{array}{l}\text { 2) Caretaker/Advisor } \\
\text { - Like teachers best who show care }\end{array}$ \\
\hline $\begin{array}{l}\text { 3) Classroom Manager } \\
\text { - quiet class was the norm }\end{array}$ & $\begin{array}{l}\text { 3) Classroom Manager } \\
\text { - orderly, but not necessarily quiet } \\
\text { classroom is the goal }\end{array}$ & $\begin{array}{l}\text { 3) Classroom Manager } \\
\text { - Most like more relaxed } \\
\text { atmosphere } \\
\text { - All want it quiet in class at times }\end{array}$ \\
\hline
\end{tabular}


knowledge", the source of the knowledge was the text books used throughout the Soviet system.

The Soviet school system was organized so that each student had a "care teacher" who was responsible for a group of students throughout the school years. Caring for students meant "making contact" with their students, "taking them on fieldtrips", and listening to them. The "care teacher" was an important person for most of the SE students.

Although Soviet students were accustomed to strict rules of conduct in their classrooms, most remembered hearing about classes that were far from disciplined. It was their expressed opinion that undisciplined classes were the result of poor teaching and poor teachers. While about half of the SE students said that they like having more freedom to talk in their ESL classes than they had in their Soviet classes, all of the students felt there were times when the class needs to be quiet. Only quiet classes, said some, "are good for thinking" and learning.

Of the seven SE students who talked about past experiences with teachers, about half had memories of positive relationships and half had memories of negative relationships. When the authority invested in the teacher combined positively with the role of the teacher, positive student/teacher relationships resulted. Negative relationships resulted when the teachers' authority was used to demean or threaten the students because of their religious convictions. 


\section{Core Values}

Table VI outlines the core values of "group", "time", and "education" and shows how these values impact SE students' participation in ESL classes. It also gives some frequently expressed educator assessments based on these student participation patterns.

As seen in Table VI, Soviet Evangelicals value group cohesiveness over individualism; they value time spent with their families and church over time spent on learning English; and while SE students appreciate learning and are good students, their life experiences have negated the practical value of higher education.

The literature and student interviews confirm that, unlike many Americans who highly value individualism and personal advancement, the SE students place greater value on the group rather than on the individual. The group with which the SE students most identify is the church.

Being part of a group has formed a cohesiveness among the Soviet Evangelicals that impacts their participation in ESL classes in several ways. First, theyhave a sense of camaraderie. Because many of the SE students belong to the same church and live in the same neighborhoods, they have relationships and interests beyond the classroom. Second, because of this sense of belonging and camaraderie, they tend to exclude those "outside" of the group. And third, being part of a group contributes to their freedom to admonish and correct one another, which is often is perceived by other nationalities, as well as by their ESL teachers, as rude and disrespectful. 
TABLE VI

CULTURAL FRAMEWORK: CORE VALUES

\begin{tabular}{|c|c|c|}
\hline CORE VALUES & IMPACT ON PARTICIPATION & EDUCATOR ASSESSMENT \\
\hline $\begin{array}{l}\text { A. Group vs. Individualism: } \\
\text { - Comraderie of Believers } \\
\text { - Group Cohesion } \\
\text { - Right to admonish/personal } \\
\text { involvement }\end{array}$ & $\begin{array}{l}\text { A. Group vs. Individualism } \\
\text { - Friendly toward other Believers } \\
\text { - Few initiate talking with non SE } \\
\text { students } \\
\text { - Correct classmates; sometimes } \\
\text { correct teachers }\end{array}$ & $\begin{array}{l}\text { A. Group vs. Individualism } \\
\text { - Egocentric } \\
\text { - Exclusive } \\
\text { - Rude and arrogant }\end{array}$ \\
\hline $\begin{array}{l}\text { B. Time: } \\
\text { - Priorities of family }>\text { church }> \\
\text { others }\end{array}$ & $\begin{array}{l}\frac{\text { B. Time }}{\text { - Many do not have time for }} \\
\text { homework or accessibility to native } \\
\text { English speakers outside of class }\end{array}$ & $\begin{array}{l}\text { B. Time } \\
\text { English }\end{array}$ \\
\hline $\begin{array}{l}\text { C. Education: } \\
\text { - Appreciation for education } \\
\text { - Higher education was not an } \\
\text { option } \\
\text { - Survival superceded education }\end{array}$ & $\begin{array}{l}\text { C. Education } \\
\text { - Good students } \\
\text { - Motivated to learn English for johs }\end{array}$ & $\begin{array}{l}\text { C. Education } \\
\text { - Low value of education } \\
\text { - Statisfied with labor jobs }\end{array}$ \\
\hline
\end{tabular}


The value that the Soviet Evangelical students place on their families and on their church impacts their use of time outside of ESL classes. Of the nine students interviewed, more than half indicated that they do not have time to do homework. The needs of their families and their personal and cultural adjustments outweigh their need to study English outside of class. All of the students who said that they do not have time for homework expressed regret, but they do not have much hope that their lives will become less complicated in the future.

The commonly expressed perception of ESL educators is that Soviet Evangelicals do not have a high value of education. Due to the limited English ability of the study participants, it was difficult to obtain in-depth input regarding the value of learning for the sake of learning. However, all but one of the SE students expressed through their words, through their past academics, and through their goals for their children a high appreciation for education. Also to be considered, is the fact that while the SE students express a high value of education, Christians have, until the last few years, been denied the benefits of higher education.

\section{IMPLICATIONS FOR TEACHING}

Approaches to and methods of language teaching are in a constant state of change. The grammar-translation method, which dominated Europe from the 1840 s to the 1940 s, is a highly teacher-centered, authoritative approach to language teaching (Richards \& Rodgers, 1992). It continues, in modified form, to be used in many places around the world. The Soviet Evangelicals' descriptions of their foreign language 
classes and their preferences for language learning all indicate a strong grammartranslation orientation.

In contrast to this structured, rule-centered approach is the communicative language approach that is popular in United States ESL classes today. With its emphasis on communicative competence, it stands in sharp contrast to the grammartranslation method.

With this contrast in mind, the ESL educators who have Soviet Evangelical students in their classes need to consider the implications of their teaching methods. Teachers who use a strong teacher-centered approach, may satisfy their SE students' need to learn grammar and guide them toward grammatical competence, but they probably will not meet their students' needs to practice life speech. Knowing that many SE students have few opportunities to communicate in English outside the classroom, and knowing that they have said they want more life speech experience, grammar-based and teacher-centered teachers need to consider adding ways to increase this element in their approach.

On the other hand, teachers who use a strong communicative approach may lead their SE students toward communicative competence, but in the process the students may become frustrated with a sense of aimlessness and confusion about classroom activities and ettiquette. Most of the SE students want to know the rules. Believing that they are not "learning" English, some of these students either drop the class or become frustrated and then become a disruptive influence in the class. 
Based on the literature and on the data gathered in this research project, Table VII sets forth some implications for teaching in the areas of methods and activities,

TABLE VII

IMPLICATIONS FOR TEACHING: METHODS \& INTERACTIONS

\section{METHODS AND ACTIVITIES}

$>$ Satisfy the felt need by consistent use of textbook or text-like materials.

$>$ Teach grammar rules; give grammar assignments; include some

"authoritative"-types of activities, like dictations.

$>$ Introduce communicative activities gradually.

$>$ Give specific, simple instructions with every communicative activity.

> Use games sparingly (they include "human bingo" as a game).

$>$ Identify TV programs appropriate for learning English that do not conflict with their values.

$>$ Do not give up communicative competence as a goal.

$>$ Comfort zones are not necessarily the best zones--stretch comfort zones gradually.

\section{TEACHER/STUDENT INTERACTIONS}

$>$ Use both class-directed and individual-directed questions.

$>$ Students unused to taking initiative may allow class to be dominated by a few bold students.

$>$ Teach and model politeness patterns:

how to get attention;

how to interrupt;

how to correct someone else; and

how to take turns.

$>$ Mix group and pair work with individual work. Start small and give lots of instructions and direction. 
and teacher/student interactions.

According to the literature, and confirmed in the interviews with the students in this study, students enter the classroom with definite expectations of teacher status, behavior, and roles. Table VIII suggests some implications for teachers as they relate to Soviet Evangelical students in their classrooms.

TABLE VIII

\section{IMPLICATIONS FOR TEACHING: THE TEACHER'S ROLE}

$>$ SE students respect authority when it is exerted---be firm and maintain control. They expect it and want it.

$>$ Demonstrate care.

$>$ Find out their needs and wants (e.g., conduct a needs analysis at the beginning of the term).

$>$ Use common areas of need as part of the lesson plan. For example:

-- How to understand household bills. (Have them to bring samples to class.)

-- How to deal with communications from a child's school.

-- How to write a resume.

. Know your own limits. This will eliminate feelings of resentment that you are being "used" by your students.

$>$ Make your "title" optional. Permit them to use your first name, last name, or "teacher."

Implications for teaching are manifold in the area of relating to SE students in the area of core values. Only a few are mentioned here. Most importantly, teachers need to honor the values of the Soviet Evangelicals. Rather than negate the value they have for the group and for the family, teachers should maximize this value. 
ESL teachers have been trained to value, and most seem to have an intuitive sensitivity to, differences between cultures. Table IX gives some implications for teaching in relating to the core values of the SE students.

\section{TABLE IX}

\section{IMPLICATIONS FOR TEACHING: CORE VALUES}

\begin{tabular}{l}
\hline Maximize the value of the group. \\
$>$ Incorporate some group activities and projects that are mono-cultural. \\
This may reduce their frustration when working with mixed groups. \\
$>$ Build "groupness" based on the ESL class (e.g., pair-projects that promote \\
mixed-culture friendships.) \\
$>$ Maximize the value of the family. \\
$>$ Assign some homework that can be incorporated into their family times \\
(e.g., activities to be done at the dinner table; to be done in the car; to be \\
done at church. \\
$>$ Bring English speakers into the class room: people, videos, tapes. \\
$>$ Teach competencies for the job market. \\
$>$ Make higher education opportunities known; keep them before the \\
students.
\end{tabular}

In conclusion, it is not the suggestion of this study that ESL teachers and administrators abandon communicative competence as a goal, nor that the communicative approach to language teaching be discarded in order to accomodate the expectations and desires of the student population of Soviet Evangelicals. However, rather than viewing the authoritative and communicative approaches as a dichotomy, 
they should be seen as a continuum. Using a cultural framework and implications for teaching derived from such a framework, ESL teachers can incorporate activities that are somewhere in the middle of this continuum. The pendulum in the field of teaching English may need to find a place in the middle of grammar-translation and communicative competence. ESL teachers should borrow the best from both methods. 


\section{REFERENCES}

Anderson, J., \& Powell, R. (1988). Cultural influences on educational processes. In L.A. Samovar \& R. E. Porter (Eds.), Intercultural communication: A reader (pp.207-214). Belmont, CA: Wadsworth Publishing Company.

Dobbert, M. (1982). Ethnographic research: Theory and application for modern schools and societies. New York: Prager Publishers.

Elwell, W.A. (Ed.). (1984). Evangelical dictionary of theology. Grand Rapids, MI: Baker Book House.

Encyclopedia Britannica,14 (pp. 30-34).(1974). Chicago, Ill: Encypliopedia, Inc.

Fetterman, D. (1989). Ethnography: Step by step. Newbury Park, CA: Sage Publication.

Fitch, K. (1986). Cultural conflicts in the classroom: Major issues and strategies for coping. In Patricia Bird (Ed.), Teaching across cultures in the university ESL program (pp. 51-62). Washington, DC: National Association for Foreign Students Affairs.

Furey, P. (1986). A framework for cross-cultural analysis. In Patricia Bird (Ed.), Teaching across cultures in the university ESL program (pp. 15-28). Washington, DC: National Association for Foreign Students Affairs.

Hall, E. (1981). The silent language. New York: Anchor Books.

Henderson, D.L. (1990). A simplified dictionary of theology. Unpublished master's thesis, Western Seminary, Portland, OR.

Hilles, S. (1991). Adult education. In Marianne Celce-Murcia (Ed.), Teaching English as a second or foreign language (2nd ed.) (pp.402-415). Boston: Heinle \& Heinle.

Information Exchange Project. (1980). Indochinese refugee reports, 1,(23), 244: Department of Refugee Affairs, Department of Health Education and Welfare. 
Kirschten, D. (1989). Bearing the burden. National Journal, 44 (pp. 2723).

LeCompte, M. \& Preissle, J. (1993). Ethnography and qualitative design in educational research (2nd ed.). San Diego: Academic Press.

Lin, K.M. (1986). Psychopathology and social disruption in refugees. In C.L. Williams \& J. Westermeyer (Eds.), Refugee mental health in resettlement countries (pp.61-73). Washington: Hemisphere Publishing Corporation.

Locke, S. \& Roberts, A. (1991). Resettlement and acculturation of Soviet Pentecostal refugees in Oregon. The ORTESOL Journal. 12, (pp. 33-49).

Merriam, S.B. (1988). Case study research in education: A qualitative approach. San Francisco: Jossey-Bass.

Muckle, J. (1990). Portrait of a Soviet school under glosnost. New York: St. Martin's Press.

Nunan, D. (1992). Research methods in language learning. Cambridge: Cambridge University Press.

Nunan, D. (1989). Understanding language classrooms: A guide for teacherinitiated action. New York: Prentice Hall.

Powell, D.E. (1975). Antireligious propaganda in the Soviet Union: A study of mass persuasion. Cambridge, MA: The MIT Press.

Richards, J.C. \& Rodgers, T.S. (1992). Approaches and methods in language learning. NY: Cambridge University Press.

Richmond, Y. (1992). From nyet to da. Yarmouth,MA: Intercultural Press.

Ripp, V. (1984). From Moscow to mainstreet. Boston: Little, Brown \& Company.

Sawatsky, W. (1981). Soviet evangelicals since World War II. Kitchener, Ontario: Herald Press.

Smart, R. (1988). Religion-caused complications in intercultural communication. In L.A. Samovar \& R.E. Porter (Eds.), Intercultural communication: A reader (pp. 62-80). Belmont, CA: Wadsworth Publishing Company.

Spradley, J. (1980). Participant observation. Orlando: Harcourt, Rinehart and Winston. 
Svitlycha, N.O. (1985). Persecution of believers in Ukraine. Religion in Communist dominated areas, 24 (3), (pp. 88-92).

U.S. Committee for Refugees. (1993). Refugee processing priorities by region, FY 94. Refugee report, 13(12), (pp. 6-11): Washington, DC.

Williams, C.L. \& Westermeyer, J. (Eds.), Refugee mental health in resettlement countries (pp.61-73). Washington: Hemisphere Publishing Corporation.

World Reflief. (1989). The challenge of refugee sponsorship. Nyack, NY: National Association of Evangelicals, USA.

Zverev, I.D. (1983). Teaching methods in the Soviet school. Paris, France: United Nations Educational, Scientific and Cultural Organization. 
APPENDIX A

REFUGEE STATISTICS 


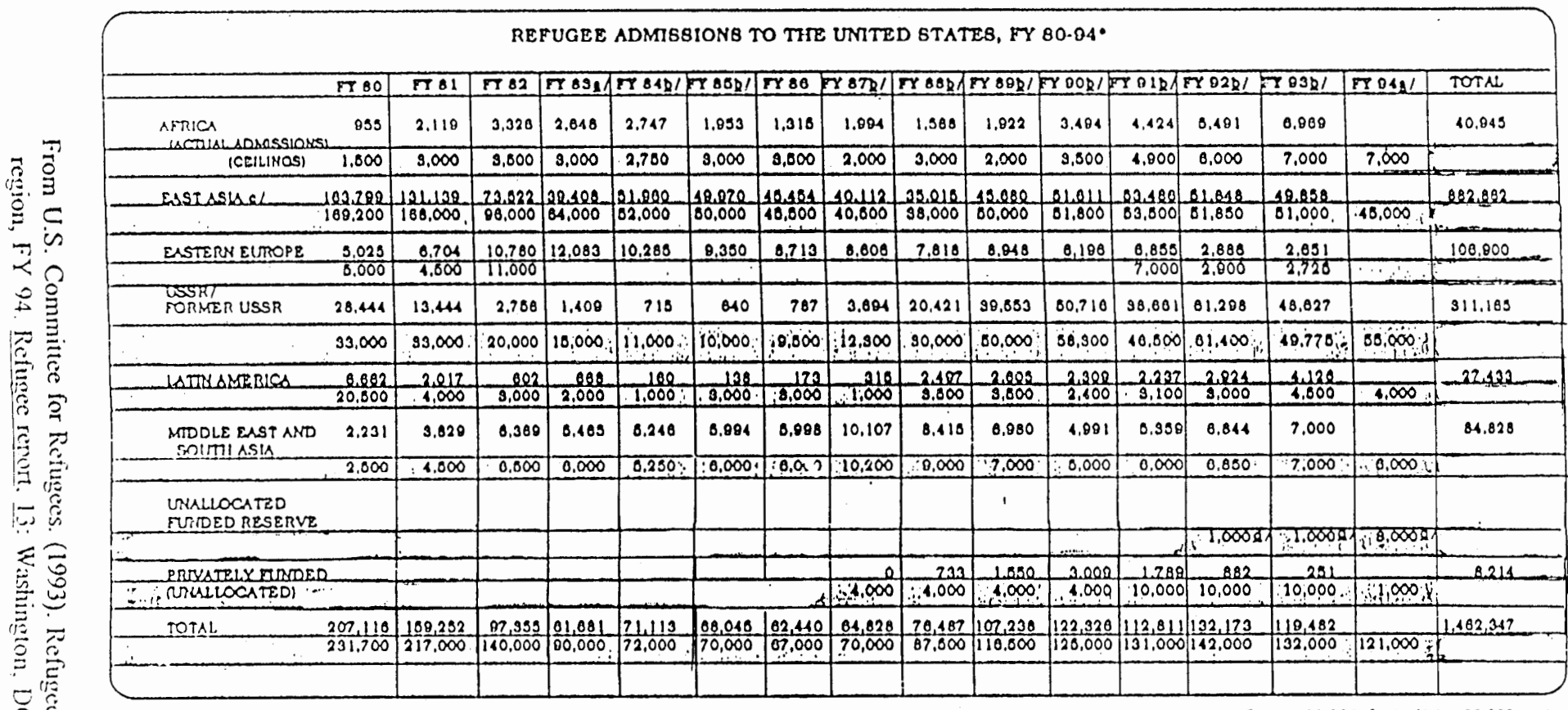

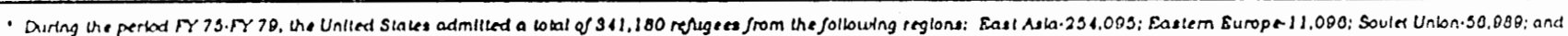
Latin Anerted 10,000 . These persone do nol appear in tris lable.

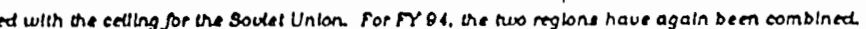

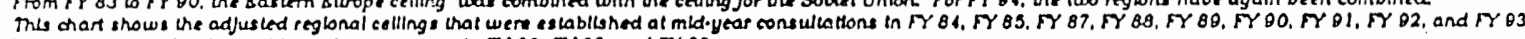

c) Cellings and actual admisstons Rgures for East Asta include both first asylum resettiement and the Orderty Deparaure Prognam (ODP) from Vectam.

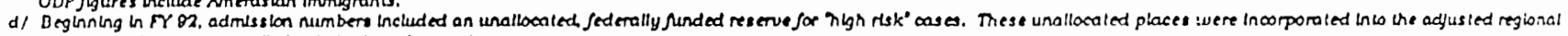

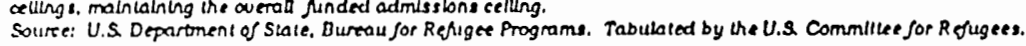




\section{APPENDIX B}

TEACHING METHODS IN THE SOVIET UNION 


\section{TEACHING METHODS IN THE SOVIET UNION}

(Letters " $\mathrm{A}$ " through "O" represent the texts surveyed)

\section{Classification of teaching methods}

TABLE 1. Nomenclature of methods as they appear in educational literature.

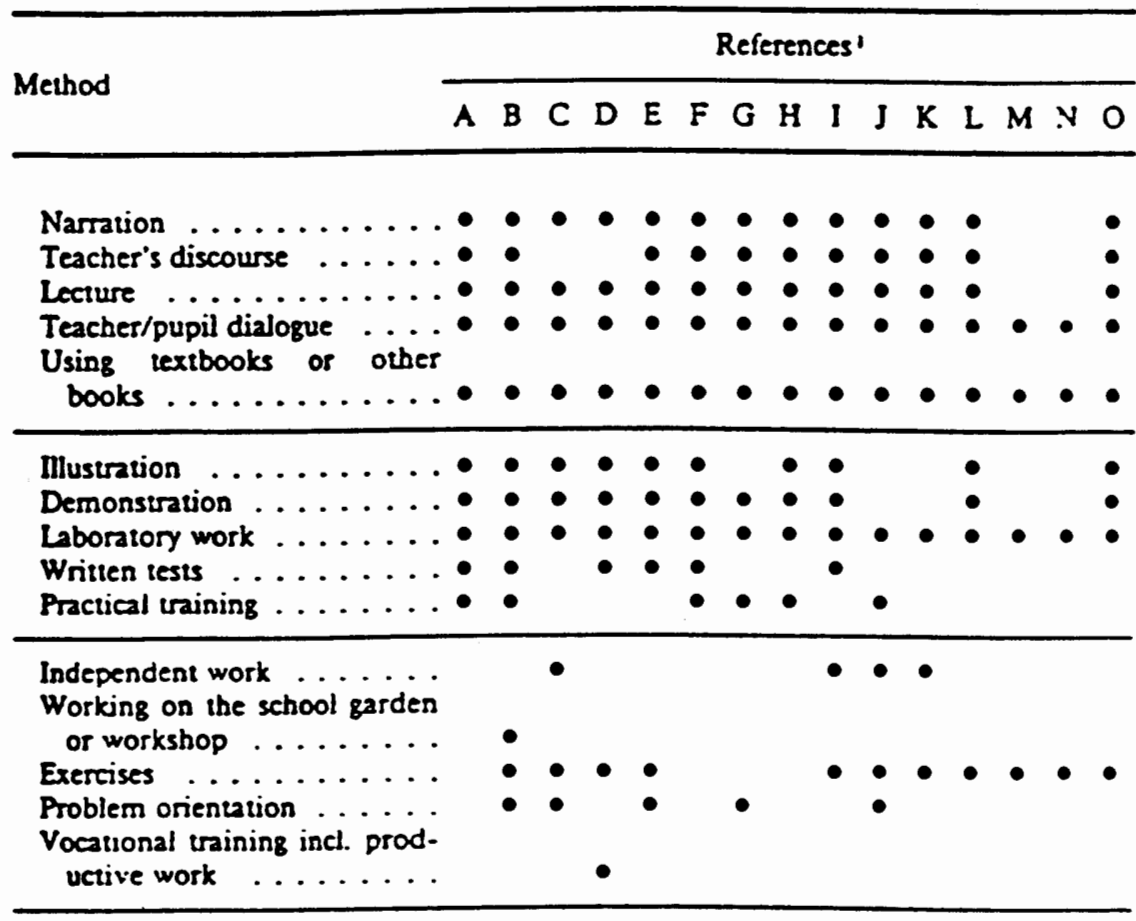

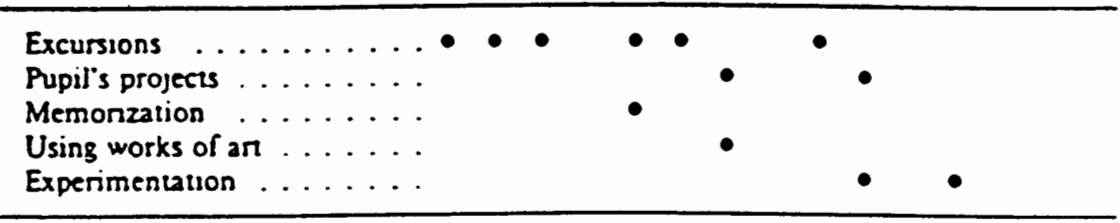

Practical application of krowiedge in new seltings..... Creatuve oral and written exercises ...........

Programmed instruction ...

Repetition ...........

Discussion ..........

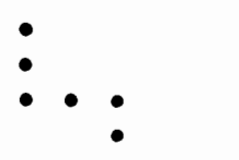

Guided discover:

Observauon ............

Methods involving evaluation and tesung

1. See reierence $[1]$ al end of chapter.

From Zverev, I.D. (1983). Teaching Methods in the Soviet School. Paris, France: United Nations Educational, Scientific and Cultural Organization. 
APPENDIX C

LETTER OF INTRODUCTION/ESL TEACHER 
Mrs Pat Wiggins

13742 S.E. Hampshire Way

Clackamas, OR 97015

Dear

As you know, I am in the process of organizing my research project for my Master's Degree in TESOL at Portland State University. I have discussed with you some of the elements of my project, but I would like to lay out my research design and my proposal for use of your ESL class as one of two study sites.

Because of the large influx of Soviet Evangelical Christians into Portland, this student population may compose as much as 30 to 75 percent of many ESL classrooms. To date, there has been very little research conducted on this particular culture group.

The purpose of my research project is to explore various aspects of the culture of the Soviet Evangelical Christians. The desired goal is that with the information gained ESL teachers will be able to make cross-cultural comparisons of teaching methods and classroom practices that will enable them to be more effective in meeting the language learning needs of this particular culture group.

My research methods are three-fold. One procedure will be classroom observations. This will require that I be a participant observer in the classroom for an extended length of time. I would like to be in the classroom one or two days a week during the research period. The research period would begin the first day of your winter term and run through the end of your winter term. Observations will include student involvement, student-student interactions, studentteacher interactions. It will not be an evaluation of teaching techniques, rather it will be student centered. During this period, I would be happy to be involved in group activities, or any other way that will be a benefit to you. Any kind of involvement will help me get to know the students, which is essential to this type of study.

A second procedure will be to administer the Strategy Inventory for Language Learning (SILL). I have a Russian translation version of this questionnaire. It takes about twenty minutes to fill out. This may reveal if there are tendencies for this student culture to strategize language learning in similar ways. If possible, I would like to administer this during one class session.

The third procedure will be to conduct interviews. This will include interviews with six to nine students, three or four from your class and three or four from another class. It will also include an interview with you, as their ESL teacher. The student interviews will take place outside of the class, so they will not intrude on class time. The purpose of the teacher interview is to gain an understanding of your perceptions and knowledge of this culture group. It will take about one hour and can be scheduled at your convenience.

I do anticipate several problems in conducting this project. First, will be the identification of the "target" group. The study is limited to those of the Christian faith. I will need to determine who those students are. Second, I understand that this group has had reasons to be 
suspicious of people outside of their group (part of the reason they are refugees). I believe that being in the classroom for awhile may help with this. But I would appreciate any suggestions.

I have talked to Mr. Noon, the director of the program. He said that he did not need to give permission for this type of study, but that teacher permission was sufficient.

Let me summarize how this study would impact your class:

Observation of students in classroom (one or two days a week/Winter term, 1994)

Administration of SILL (ten minutes to explain it, twenty minutes to take it)

Student interviews (outside of class)

Teacher interview (one hour outside of class)

If, after reviewing this letter, you are willing to grant permission for your class to be one of two research sites, please sign below. If you have any questions regarding any part of the study, please feel free to ask me about it. Also, Marge Terdal, my research advisor, would be happy to talk with you if you have any questions or concerns. She can be reached at: $725-4142$.

Thank you for all the help you have already been to me. I have appreciated your experience as an ESL teacher.

Sincerely,

Pat Wiggins

I understand the elements of this research project and I am willing for my class to be used as a research site.

Name

Date 
APPENDIX D

FIELDNOTES/SAMPLE 
Level 2

$1 / 26 / 94$

This is the third time $I$ have observed this class. Today I arrived within a few minutes of class start time. I was pleased to see and her husband, in class today. They

have been outgoing toward me. They sat at table 1, near where I took a seat. The seat was stained and quickly got a clean one for me. looks' different from the other Russian's. She wears make-up (eyeliner and mascara) and her hair is colored and up in a french roll.

The teacher got in class and left because she forgot to get something from her car. She was back by 9:08. I told her that I would slip out for about 15 minutes at 10:00 to meet with some students from the level 4 class.

9:00 Listening and speaking exercise.

There is an overhead of story - pictures in correct order. They must listen as the teacher tells the story. She explains that they will listen and then they will have a paper with pictures out-of-order. They will talk in pairs aid get them back in order.

As I look around the room, all the students are watching the teacher. Perhaps they have done this before and know the importance of listening and looking at the overhead. At any rate, they are all very attentive.

At 9:12 a young Vietnamese man enter. The teacher says, "It'sten after nine" (points to her watch). "Don't be late, I saw you out there at 9:00." He took a seat at table 1.

During the time the teacher told the story, the Russian women at table 4 spoke quietly together during part of this activity.

9:20 "Now I'm going to give you this. This is for speaking, not for writing." (she begins to pass out the worksheet with out-of-order pictures) "You can work in pairs. No pencils. Let's try it. No pencils. No pencils. Oh, except for numbers, yes."

The students are to work in pairs. They are to talk about the pictures and decide which comes first, second, etc. The teacher separate some students, including. and , and puts some together in pairs. Tries to mix language groups.

As I observe the class I look for who is speaking English. who initiates. Who is speaking L1. I got up and walked around. One Russian pair ( and another man) are speaking Rrussian (or L1). I said quietly, with a smile, "That doesn't sound like English." for awhile. turned and said, "Yes, thank you." He smiled and they began speaking English --

I went to table 1 and Vietnamese woman. I hadn't been able to see the overhead from where I sat (I wonder how well they could see it) and I hadn't listened closely to the story, so I really wasn't sure of the order. But attempted to speak English with me. Not, however, with the Vietnamese woman. Both worked independently of eachother. I wonder if they were shy, lacking confidence to initiate with one another. As the three of us looked at the paper we didn't get very far. I said, "this is very hard." 
I went to table 7. A russian man spoke English with me. He was quite good. He had all the pictures in order. When I suggested a possible different order, he said, "No, I remember from the board."

I went to table 4. One Russian woman talked about the pictures with me. Others helped. She made errors, stumbled in her English, but she didn't give up. The next woman was better. Then I spoke with an older Vietnamese woman. She was better still. She spoke the best English of any of the students I have spoken with today.

The teacher called the class back together. I sat down in my seat.

She calls on certain students to put a sentence on the board so that each picture is described in sequence. In order to do this correctly, the students must have decided on the order of the pictures and must now work together to write an accurate description of the picture frame.

Table 1 - The Vietnamese and Russian were a pair, but never spoke to eachother. This Vietnamese woman hasn't initiated or spoken with the other Vietnamese either (at lease that I have observed). Even as I am thinking this thought, she looks up at the board and reads the sentence that put up. (his picture frame was the grandpa phoning 9-1-1) It was something like: Hello, 911, there is a fire in my house. Please send fire truck. How is the weather today? I am fine, thank you."

As she read the sentence she smiled and laughed. It is the first time I have seen her smile. She and the other vietnamese woman enjoyed it.

The man at table 1 worked together to come up with a sentence. spoke with the other Vietnamese woman. They

As the students write their sentences on the board, many of the students seated wrote down their sentences on their worksheets or in their spiral notebooks. All of the sentences had been written on the board, and the teacher had to call on to come up and put his sentence on the board. He was not an eager participant. He walked slowly to the board. Teacher said, "it'sokay, I'll help you." He wrote the sentence on the board, but made several errors. The teacher made suggestions and several of the other students and especially audible) corrected as well. It seemed that was happy to sit down.

The teacher went over the sentences on the board, correcting grammar and offering better sentence structure. I wasn't able to. stay for all of this because it was 10:00 and I slipped out to go to "John's" class.

10:00

I went into John's class and stood by the wall. He collected papers and then asked (and called by name the four Soviet students) to go with Pat for reading preference something.

We went into the same room that $I$ had used before. Today there were four individuals and John said he thought that was the rest of that student population.

I reintroduced myself and told the students what I was doing and why and gave them my letter of request and asked them to read it. In this group there was , and 
APPENDIX E

OBSERVATION ANALYSIS SYSTEM 


\begin{tabular}{|l|l|l|l|}
\hline & SE Students & Other Students & Class \\
\hline $\begin{array}{l}\text { 1. Teacher asks a display question (i.e. a question } \\
\text { to which she knows the answer }\end{array}$ & & & \\
\hline $\begin{array}{l}\text { 2. Teacher asks a referential question (i.e. a } \\
\text { question to which she does not know the answer) }\end{array}$ & & & \\
\hline 3. Teacher explains a grammatical point & & & \\
\hline 4. Teacher explains meaning of a vocabulary item & & & \\
\hline 5. Teacher explains functional point & & & \\
\hline 6. Teacher explains point reiating to the content \\
(theme/topic) of the lesson
\end{tabular}

Date:

Class level:

Time:

Type of activity observe: 
APPENDIX F

LANGUAGE LEARNING PREFERENCE SURVEY 


\section{HOW DO YOU LIKE TO LEARN BEST?}

1. In English class, 1 like to learn by reading.

2. In class, I like to listen to and use cassettes.

3. In class, I like to learn by games.

4. In class, I like to learn by conversations.

5. In class, I like to learn by pictures, films, video.

6. I want to write everything in my notebook.

7. I like to have my own textbook.

8. I like the teacher to explain everything to us.

9. I like the teacher to give us problems to work on.

10. I like the teacher to help me talk about my interests.

11. I like the teacher to tell me all my mistakes.

12. I like the teacher to let me find my mistakes.

13. I like to study English by myself (alone).

14. I like to learn English by talking in pairs.

15. I like to learn English in small groups.

16. I like to learn English with the whole class.

17. I like to go out with the class and practise English.

18. I like to study grammar.

19. I like to learn many new words.

20. I like to practise the sounds and pronunciation.

21. I like to learn English words by seeing them.

22. I like to learn English words by hearing them.

23. I like to learn English words by doing something.

24. At home, I like to learn by reading newspapers, etc.

25. At home I like to learn by watching TV in English.

26. At home, I like to learn by using cassettes.

27. At home I like to learn by studying English books.

28. I like to learn by talking to friends in English.

29. I like to learn by watching/listening to Australians.

30. I like to learn by using English in shops/CES $/$ trains... no a little

no a litule

no a little

no a little

no a little

no a little

no a little

good

good

good

good

good

good

good

best

best

best

best

best

best

best

no a little

good

good

good

good

good

best

best

best

best

best

good best

good best

good best

good best

good best

no a little

good best

good best

good best

good best

good best

good best

good best

good best

good best

good best

good best

good best

good best

\section{Type 1: 'Concrete' learners}

These learners tend to like games, pictures, films, video, using cassettes, talking in pairs and practising English outside class.

\section{Type 2: 'Analytical' learners}

These learners like studying grammar, studying English books and reading newspapers, studying alone, finding their own mistakes and working on problems set by the teacher.

\section{Type 3: 'Communicative' learners}

These students like to learn by watching, listening to native speakers, talking to friends in English and watching television in English, using English out of class in shops, trains, etc., learning new words by hearing them, and learning by conversations.

Ty.pe 4: 'Authority-oriented'learners

These learners prefer the teacher to explain everything, like to have their own textbooks, to write everything in a notebook, to study grammar, learn by reading, and learn new words by seeing them. 


\section{APPENDIX G}

LETTER OF INTRODUCTION TO SE STUDENTS/INFORMED CONSENT 


\section{LETTER OF INTRODUCTION AND INFORMED CONSENT (ENGLISH)}

Dear

I would like to introduce myself and to ask for your help.

My name is Pat Wiggins. I am a graduate student at Portland State University studying to become an English language teacher. I am currently working on a research project that involves several of the English classes at Community College. I think it is also important for you to know that I, too, am a Christian. My husband was a pastor for eight years and now works in a Christian college.

I would like to ask for your help with my research project. As you know, many Christians from former Soviet countries are coming to the United States. Many of them, like you, are in English language classes to learn enough English to go shopping. talk with their neighbors, and get jobs. In order for teachers to do an effective job of teaching English, it is important for them to know what their students like and don't like about American teaching methods and classroom activities. Teachers also need to know what their students' classes were like "back home".

Just as you and others may abe finding that many American customs are different from your own customs, you also may abe finding that your English class, or your children's classes, are different from classes in you homeland. It is very important for teachers to understand these differences so that they can be more effective in helping you and others learn English.

From January to March I am going to be observing several English classes at College. I will also be interviewing some students to learn about the similarities and differences in culture and education. In the interviews I will ask questions about the students' past educational experiences, their personal religious faith, and their desires for learning English. After I feel that I have a good understanding of their wants, needs, likes, and dislikes, then I will put together their ideas and suggestions in a way that, hopefully, will help English language teachers be better educators of those who will come to America in the years ahead.

I would like to ask you to consider being one of the students I interview. If you are willing to meet with me it would be at a time that is convenient for you. This is completely voluntary. It will not affect your grade in class. During the interview, you can answer or not answer any questions you want. You many also stop the interview at any time. Anything you share with me will remain confidential. You English teacher has agreed to this project and know that any information shared with me will remain private.

The interview will need to be in English, unless you know of someone who would enjoy interpreting for us.

If you agree to meet with me, the interview will be one hour long. It is possible that we could meet two times if necessary, or if you would like to. But I think one hour will be enough.

Attached to this letter is a consent form that you need to read and sign if you agree to take part in an interview. Whatever your decision, thank you for letting me introduce myself and for reading this letter.

Sincerely your in Christ,

Pat Wiggins 
I, Language Learning of Students From Former Soviet Countries.

,agree to take part in this research project on English

I understand that the study involves one or two interviews with the researcher (Pat Wiggins), during which time she will ask me questions regarding my prior school experiences, some of my religious understandings as a Christian, and my recent experiences of learning English. The interview will last about one hour and will be tape recorded; I can answer any questions I want; and I can stop the interview at any time. I understand that this interview is voluntary and will in no way affect my grade in my English class. I have been told that I may choose to have an interpreter present during the interview. I understand that the interview times will be outside of my English class.

Pat Wiggins has told me that the purpose of the study is to help English language teachers become better educators of students from former Soviet countries by increasing the teachers' awareness of similarities and differences in American teaching and learning styles and the teaching and learning styles experienced by students from former Soviet countries. I understand that I may not receive any direct benefit from taking part in this study. But the study may help to increase knowledge that may help others in the future.

Pat Wiggins has offered to answer any questions I have about the study and what I am expected to do.

She has promised that all information I give will be kept confidential and that the names of all people in the study will remain anonymous.

I have read and understand the above information and agree to take par in this study.

Date:

Signature:

Phone number:

If you have any concerns or questions about this study, please contact the Chair of the Human Subjects Research Review Committee, Office of Research and Sponsored Projects, 105 Neuberger Hall, Portland State University, (503)725-3417. 
Уважаемнй (-ая)

Разрашите мне представиться и попросить вашего содействия.

Меня зовут Пэт Уиггинс. Я аспирантка в Портлендском государственном универсктөте, обучающаяся по специальности «преподавание английского язика». В настоящев время я работаю над дипломнмм провктом, КоторАй охватнвает несколько курсов английского язнка в Портлендском Государственном колледже (РСС). Я также считаю, что вам будет важно знать. что я тоже христианской вөрк. Мой муж бил пастором на портяжөнии восьми лет ии сөйчас работавт в христианском колледхе.

я прошу вашего содвйствия в моөй научной работе. Как вн знаете, много христиан из республик бшвшего Советского Союза приезжавт жить в Совдиненние Штати. Многив из них, так же как и вы, слушают курсн по англиїскому яз山ку для того, чтобн приобрести достаточно язнковых навыков для посещения магазинов, общения с соседями и успешного поиска работы. Чтобы преподавание английского языка било зффектиеным, учителям необходимо знать, что в американских методах преподавания нравиться или не нравиться их студентам. Им также необходимо знать, каково било преподавания - бhBuen COBetckom CON38.

Как ви. Так и многие другие обнаруживают, что американские обнчаи отличаются от ваших обнчаев. Вы, вероятно, также находите, что ваши занятия по английскому язшку или занятия В школе ваших детей отличаются от занятий - вашей бшвшей стране. Преподавателям очень важно понимать эту разницу, для того чтобы помечь вам и другим студентам освоить английский язик.

С января по март я буду наблюдать несколько курсов английского язнка В Портлендском государственном колледхе (РСС). Я также буду опрашивать некотормх студентов о сходствах и различиях в культуре и в систвме образования. Во время интврвью я буду задавать студентам вопросш об их предмдущем опыте обучения, их личных религиозных езглядах и их желании освоить английский язшк. После того, Ках. по мовму мнению, у меня пояеится Хорошев понимание их потрөбностей и предпочтений, я опищу их мнения и предложения в таком виде, который, я надеюсь, поможет преподавателям английского язшка улучшить их преподавание төм, Кто будет приезжать жить в Америку в будущем.

Я прошу вас подумать о том. чтобы бнтЬ одним и тех студентов, которшх я буду опрашивать. Если вы согласитесь запланировать интервью со мной. то зто будвт В наибалев удобное для вас время. Это абсолютно добровольно и никак не повлияет на вашу оценку в классе. Во время интервью вн можвте отвечать или не отвечать на любне вопросы. Вы такЖе можете прервать интервью в любой момент. Вся предоставленная вами информация останется конфиденциальной. Ваш преподаватель согласился на участие в этой работе и знавт. что вся информация будет предоставлена в частном порядке. Если вн хотитө дать интеврвьо по-английски. это будет очень хорошо. Однако, өсли ви желавте присутствие переводчика, я смогу это организоват.

Если вы согласитесь встретиться со мной, интервью будет примерно продолжительностью в один час. При возможности или по вашему желанию. мы можем встретиться два раза, хотя я думаю, что одного часа будет достаточно.

Я прилагаю форму письменного согласия на участие в научной работе. хоторую вам необходимо прочитать и завврить свовй подпиеьо. если ви согласитесь на участие. Каково бн ни бнло ваше решение, $я$ благодарю вас за ваше вниманив $K$ моему письму и за предоставленную мне возмохность познакомитьСя С вами.

Искрене ваша во христе. Пзт Уигтинс. 


\section{Письменное поптверждение согласия на участие в научно- исспедовательской работе.}

\section{9.} согласен (согласна) принять участие в научой работе «Освоение английского языка обучающимися из республик бывшего Советского Союза».

я сознаю. что работа включаөт в себя одно или два интервью с исследователем (Пзт Уиггинс), в ходе которых она будөт задавать мне вопросы о моем предыдущем обучении. некоторых моих религиозных (христианских) взглядов на жизнь, а также о мовм недавнем опите обучения английскому языку. Интөрвью будет продолжаться приблизительно один час и будет записано на магнитофонную пленку. Я могу отвечать на вопросы по моему усмотрению, и я могу прекратить интервью в любой момент. Я сознаю, что интервью добровольно. И не в коей мере не повлияет на мою оценку по английскому языку. Меня проинформировали, что я могу просить о присутствии переводчика во время интерью. я созннаю, что интервью будет запланировано не в учебнов время.

Пэт Уиггинс сообщила мне, что цель этоой научной работы - помочь преподавателям английского языка улучшить свое преподавание студентам из бывшего Советского Союза путем повышения их инфромированности о сходствах и различиях между американским стилем обучения и стилем обучения. привычным для людей из бывшего Советского Союза. Я сознаю. что я не получу прямого вознаграждения за участие в этой научной работе. но сама работа предоставит информацию, которая поможет другим в будущем.

Пэт Уиггинс согласилась ответить на любые вопросы, которые могут у меня появиться в отношении этой работы или моего участия в ней.

Она гарантирует, что вся предоставленная мной информация останется конфиденциальной, и имена людей будут изменены или опущены.

я прочитал(а) вышеуказанный текст и согласен (согласна) принять участия в этой научной работе.

Число:

Подпись:

Номер телефона:

Если у вас есть вопросы или сомнения относительно зтой работы, пожалуйста, обратитесь $K$ председателю комитета по научно-исследовательской работе с людьми. Office Of Grants and Contracts, 105 Newberger Hall, Portland State University, (503)725 - 3417. 
APPENDIX H

INTERVIEW GUIDE 
Interview Questions for Soviet Evangelical Christians

\section{1) Please tell me about you family}

\section{- Name}

- Number of children; "Number of brothers/sisters

- City and country

- How long in US

- Occupation in home country/now

2) What was the city like you grew up on

\section{- Large/small}

- Industrial/rural

3) Please tell me about your school

- What did the building look like/the classroom look like

- Were there overhead projectors, did you see videos

- Were there maps/decorations

\section{4) Let's talk about your teachers}

- What did you call your teachers?

- Tell me about a teacher you liked

- What did s/he do

- Why did you like him/her more than others

- Tell me about a teacher you didn't like

- Did leacher treas you differently than they treated other children who were not Christians? - how?

- How did your teachers discipline students?

\section{5) How were teachers treated by their students?}

- Did they call them by first name?

- Did students ever disagree with their teachers?

- Did you feel a close friendship with any of your teachers?

- Did ieachers do things outside of class with their students?

\section{6) L would like to know what you actually did in your classes}

- Did you have to come to class every day? What happened if you skipped school?

-What was it like in the classroom? Did students talk to eachother? Was it noisy/quiet?

- Did you like going to school?

- Were there class discussions or was it primarily lecture?

- Did you take notes?

- How did you get your teacher's attention?

- How did the teacher teach? Drills, dictation, memorization, lecture, assign papers, do skits

- Did you do your work alone or work in pairs or small groups?

- Did you have homework?

\section{7) What was your parents' opinions of education?}

- Did they help you with your homework?

- Did they enforce a homework schedule?

- Did they want you to make good grades?

\section{8) Could Christians ge on to university or institutes?}

- If yes, did many of your friends go to university?

- If not, what kind of work did your friends do?

- Were these occupations adequate for earning a good living?

- If you could do anything, have any occupation, what would it be? What about for your children?

\section{8) Now I'd like to talk with you about your ESL classes and American schools in genera}

- How many ESL teachers have you had?

- How long have you been in an ESL program?

- Had you studied English prior to US

- Why are you in ESL classes now?

* For men: how many men started in ESL classes with you?

Do you know where these men are now?

- How are your ESL classes different from your classes in homeland?

- Kinds of students in class

- kinds of activities in class

- homework

- How are your American teachers different than native teachers?

- talk about personal lives

- topics of discussion/political, religious, personal

- If you could change anything about ESL class what would you change? 


\section{APPENDIX I}

\section{INTERVIEW TRANSCRIPT}


Student Interview \#4

February, 16, 1994

11:30 a.m. in Cubicle at Literacy Lab

This is an interview with a gentleman probably in his 40 s. He is fairly tall, has dark hair that is beginning to gray. He attends class regularly. He appears somewhat bored in class at times. However, he is usually quite ready to participate in speaking activities.

Today I was originally scheduled to meet with someone else after class. However, due to family needs she couldn't meet after class. I approached P during a quiet moment in class and asked him if he could meet with me today after class. He didn't hesitate to say yes. I felt that it was okay to ask him at such short notice because last week he suggested meeting on a same day basis, but I wasn't able to do so.

We got situated in the cubicle and I gave him the consent form to read and sign. I reminded him that I would record the interview so I wouldn't need to write while he speaks.

INT: First, please tell me about yourself.

PB: I have eight children. Three boys and five girls. My older son 19 years old and my youngest daughter 8 months old. I came here from former Soviet Union. Republic, Kyrgystan. City, Frunze, capitol of Kyrgystan.

INT: Where is that located in the former Soviet Union?

PB: Yeah, umm, This is area south.

INT: South? Okay, so there's Kazakhstan. I know Kazakhstan.

PB: Kazakhstan, yeah. Next to Kazakhstan.

INT: Okay, and this city, is it a big city?

PB: Yeah, it about 800,000 people.

INT: That's a pretty big city. Did you live in the city, or outside of the city?

PB: I live in the city.

INT: What did your father do as an occupation?

PB: My father was work factory work. He was mechanic. 
INT: Your mother, did she work outside the home?

PB: Yes, she worked in factory, same factory.

INT: And then, what about you. Did you work in the factory also? Or what did you do?

PB: I got some education. And work in music college as piano tuner. I finished music college as choir director. Now I in the church. we have Russian

INT: Yes, I know about that.

PB: Oh? We have choir about 35 people. A Russian choir.

INT: Are you in the choir or do you direct the choir?

PB: I'm direct the choir.

INT: What are you hoping to do as an occupation? Do you have a job right now?

PB: Right now I don't have occupation.

INT: Well, you can tune pianos?

PB: Yeah, I can do it. But now I do something in my house. I build, make, violins. I did it six violins now, but I try to made them better and better. (laughs)

INT: Okay, let's talk about school. First of all tell me about a teacher you liked.

PB: She was woman. She can to find contact between student and between her. She build, or make good atmosphere in the class.

INT: Was this an elementary school teacher?

PB: Yeah.

INT: So, did you have her for four years?

PB: Three years.

INT: She was kind to the students?

PB: Yeah

INT: Some of the people I've talked to said that their teachers were not kind to them because they were not Christians. How was that for you? Did your teachers ever treat 